\title{
Functional Characterization of Cytochrome P450 Hydroxylase YpmL in Yangpumicin A Biosynthesis and Its Application for Anthraquinone-Fused Enediyne Structural Diversification
}

\author{
Dong Yang, ${ }^{\dagger, \S, \perp}$ Fei Ye, ${ }^{\dagger, \perp}$ Christiana N. Teijaro, ${ }^{\dagger}$ Dobeen Hwang, ${ }^{\prime}$ Thibault Annaval, ${ }^{\dagger}$ Ajeeth \\ Adhikari, ${ }^{\dagger}, \|$ Gengnan Li, ${ }^{\dagger}$ Xiaohui Yan, ${ }^{\dagger}$ Chun Gui, ${ }^{\dagger}$ Christoph Rader, ${ }^{\|}$Ben Shen ${ }^{\dagger, \downarrow, \S, *}$ \\ ${ }^{\dagger}$ Department of Chemistry, ‡Department of Molecular Medicine, §Natural Products Discovery \\ Center at Scripps Research, "Department of Immunology and Microbiology, The Scripps \\ Research Institute, Jupiter, FL 33458, USA
}

$\perp$ These authors contributed equally

*Correspondence to: E-mail: shenb@scripps.edu, Tel: (561) 228-2456; Fax: (561) 228-2472

\section{Supplementary Information (SI)}

\section{Supplementary Materials and Methods}

Table S1 Strains and plasmids used in this study

Table S2

Table S3

Oligonucleotides used in this study

NMR spectroscopic data for 14-17

Figure $\mathbf{S 1}$

Figure S2

Figure S3

Figure S4

Figure S5

Figure S6

Figure S7

Figure S8

Figure S9

Figure S10

Figure S11
Characterization of YpmL as a cytochrome P450 HR-ESI-MS spectrum confirming the identity of the product as 4 HR-ESI-MS spectra of the products of in vitro YpmL-catalyzed hydroxylation with $7, \mathbf{8}, \mathbf{9}, \mathbf{1 0 , 1 1}$ and $\mathbf{3}$ as substrates, respectively HPLC-MS analysis of crude extracts of SB20025 (ii) with wild-type CB03234 (i) as a control HR-ESI-MS and NMR spectra of 14 HR-ESI-MS and NMR spectra of 15 HR-ESI-MS and NMR spectra of 16 HR-ESI-MS and NMR spectra of 17 Key 2D NMR correlations of 14-17 Cytotoxicity assay of 14-17

Plasmid relaxation assay of 14-17
S2-S5

S6

S7

S8

S9

S10

$\mathrm{S} 11$

$\mathrm{S} 12$

S13-16

S17-20

S21-24

S25-28

$\mathrm{S} 29$

S30

S31

S32

\section{Supplementary References}


General experimental procedures. The ${ }^{1} \mathrm{H}$ and ${ }^{13} \mathrm{C}$, and 2D NMR (HSQC, ${ }^{1} \mathrm{H}-{ }^{1} \mathrm{H}$ COSY, HMBC, and ROESY) spectra were collected with a Bruker AVANCE AV600 spectrometer $\left(600 \mathrm{MHz},{ }^{1} \mathrm{H}\right.$ $\mathrm{NMR}$ for ${ }^{1} \mathrm{H}$ and $150 \mathrm{MHz}$ for ${ }^{13} \mathrm{C}$ nuclei). Structural assignments were made with additional information from gCOSY, gHSQC, and gHMBC experiments. Optical rotation values were measured using an Autopol IV automatic polarimeter (Rudolph Research Analytical). HPLC-MS analysis was performed on an Agilent 1260 Infinity LC coupled to a 6230 TOF (HRESI) with an Agilent Poroshell 120 EC-C18 column $(2.7 \mu \mathrm{m}, 50 \mathrm{~mm} \times 4.6 \mathrm{~mm})$. Column chromatography was conducted on Sephadex LH-20 (GE Healthcare, Glies, UK). Semipreparative HPLC was carried out on a Varian liquid chromatography system with a YMC-pack ODS-A ( $250 \mathrm{~mm} \times 10 \mathrm{~mm}, 5 \mu \mathrm{m})$ column. MPLC purification was conducted on Biotage Isolera One using a Biotage SNAP Catridge KP-C18-HS column (30 g). Fermentation was carried out in New Brunswick Scientific Innova 44 incubator shakers.

Bacterial strains and culture conditions. Strains and plasmids used in this study are listed in Tables S1. PCR primers were obtained from Sigma-Aldrich (Tables S2). DNA polymerase, restriction endonucleases, and T4 DNA ligase were purchased from New England Biolabs (NEB) and used by following the protocols provided by the manufacturers. DNA amplification and mutagenesis were performed with a S1000 Thermal cycler (Bio-Rad). DNA gel extraction and plasmid preparation kits were purchased from Omega Bio-Tek. DNA sequencing was conducted by Eton Bioscience. All common biochemicals and culture media components were purchased from commercial sources. E. coli strains containing plasmid were cultured in lysogeny broth (LB) with the appropriate antibiotic. Streptomyces strains were grown on ISP-4 medium at $28{ }^{\circ} \mathrm{C}$ for sporulation or cultured in liquid tryptic soy broth (TSB) at $28{ }^{\circ} \mathrm{C}$ and $250 \mathrm{rpm}$, with appropriate antibiotic selection, if needed.

Gene expression and protein overproduction and purification. Micromonospora yangpuensis DSM 45577 was purchased from DSMZ (Genbank accession number NZ_FMIA01000002.1 for whole genome shotgun sequences). ${ }^{\mathrm{S} 1}$ The $y p m L$ gene (NZ_FMIA01000002.1 complement 3915090-3916283) was amplified by PCR from genomic DNA of $M$. yangpuensis and using the primers YpmL-F/YpmL-R (Table S2) and Q5 High-Fidelity DNA Polymerase (NEB) following the protocol provided by the manufacturer. The PCR product was purified, treated with T4 polymerase (NEB), and cloned into pBS3080 ${ }^{\mathrm{S}}$ according to ligation-independent procedures ${ }^{\mathrm{S3}}$ to give pBS23001. Plasmid pBS23001 was transformed into E. coli BL21 (DE3). The cells were grown in LB supplemented with $0.1 \mathrm{mM}$ of 5 -aminolevulinic acid and $0.1 \mathrm{mM}$ of $\mathrm{FeCl}_{3}$ at $37{ }^{\circ} \mathrm{C}$ until an $\mathrm{OD}_{600}$ of 0.6 was reached. The cells were cooled to $4^{\circ} \mathrm{C}$, the genes were induced by addition of $0.1 \mathrm{mM}$ of isopropyl $\beta$-D-1-thiogalactopyranoside. The cells were grown at $18{ }^{\circ} \mathrm{C}$ for $16 \mathrm{~h}$. The cells were harvested at $4000 \mathrm{~g}$ for $15 \mathrm{~min}$ at $4{ }^{\circ} \mathrm{C}$ and the pellet was resuspended in lysis buffer (100 mM Tris, pH 8.0, containing $300 \mathrm{mM} \mathrm{NaCl}, 15 \mathrm{mM}$ imidazole, and $10 \%$ glycerol). After sonication, the cell debris was removed by centrifugation at $15000 \mathrm{~g}$ for $15 \mathrm{~min}$ at $4{ }^{\circ} \mathrm{C}$. The lysate was loaded onto a HisTrap $5 \mathrm{~mL}$ column (GE) equilibrated with washing buffer $(50 \mathrm{mM}$ Tris, $\mathrm{pH}$ 8.0 , containing $100 \mathrm{mM} \mathrm{NaCl}$ and $15 \mathrm{mM}$ imidazole). The column was washed with washing buffer and the $\mathrm{His}_{6}$-tagged protein was eluted using elution buffer $(50 \mathrm{mM}$ Tris, $\mathrm{pH} 8.0$, containing 100 $\mathrm{mM} \mathrm{NaCl}$ and $300 \mathrm{mM}$ imidazole). Following elution, the protein was diluted three times using 50 mM Tris, pH 8.0 buffer. The protein was loaded onto a HiTrap Q HP $5 \mathrm{~mL}$ (GF) equilibrated with washing buffer (50 mM Tris, $\mathrm{pH}$ 8.0). The column was washed with washing buffer and the protein was eluted using a gradient of elution buffer $(50 \mathrm{mM}$ Tris, $\mathrm{pH} 8.0$, containing $1 \mathrm{M} \mathrm{NaCl})$. Finally, the protein was injected onto a Superdex $S 7516 / 600$ gel filtration column (GF) using $50 \mathrm{mM}$ Tris, $\mathrm{pH} 8.0$ buffer containing $100 \mathrm{mM} \mathrm{NaCl}$ and stored at $-80^{\circ} \mathrm{C}$.

Analytical size-exclusion chromatography. The molecular weight (MW) and monomeric state of YpmL (NCBI Accession WP_091439365.1) in solution was determined by size-exclusion chromatography using a HiLoad 16/600 (16 × $600 \mathrm{~mm}$ ) Superdex 75 column (GE Healthcare) 
connected to a GE Healthcare ÄKTA pure HPLC system. The column was pre-equilibrated with two column volumes of $50 \mathrm{mM}$ Tris, $\mathrm{pH} 8.0$, containing $100 \mathrm{mM} \mathrm{NaCl}$, and calibrated with carbonic anhydrase $(29 \mathrm{kDa})$, ovalbumin $(43 \mathrm{kDa})$, albumin $(66 \mathrm{kDa})$, conalbumin $(75 \mathrm{kDa})$, alcohol dehydrogenase $(150 \mathrm{kDa})$ and $\beta$-amylase $(200 \mathrm{kDa})$. The chromatography was carried out at $4^{\circ} \mathrm{C}$ at a flow rate of $1 \mathrm{~mL} \mathrm{~min}^{-1}$. Data analysis was performed using the Unicorn 7.0.2 software (GE Healthcare).

P450 spectral assay ${ }^{\mathrm{S}}$. YpmL was diluted in $100 \mathrm{mM} \mathrm{K}_{2} \mathrm{HPO}_{4}, \mathrm{pH} 7.5$ containing $1 \mathrm{mM}$ EDTA, $20 \%$ glycerol, $0.5 \%$ sodium cholate and $0.4 \%$ Triton N-101 to a final concentration of $50 \mu \mathrm{M}$. Then, $1 \mathrm{mg} / \mathrm{mL}$ of $\mathrm{Na}_{2} \mathrm{~S}_{2} \mathrm{O}_{3}$ was added to reduce the protein. Beforehand, half of the protein was bubbled with $\mathrm{CO}$ gas for $1 \mathrm{~min}$. Then a UV-vis spectrum of the ferrous-YpmL and the ferrous-YpmL-CO was measured. The ferric-YpmL was used as a blank (Figure S1C).

In vitro Assay of YpmL. Enzymatic reactions were performed in $50 \mathrm{mM}$ sodium phosphate buffer, $\mathrm{pH}$ 7, containing $100 \mu \mathrm{M}$ of substrate, $10 \mu \mathrm{M}$ of $\mathrm{YpmL}$, and $5 \mathrm{mM}$ of $\mathrm{H}_{2} \mathrm{O}_{2}$, in a total volume of 50 $\mu \mathrm{L}$ for 1 hour at $28{ }^{\circ} \mathrm{C}$. Each reaction was quenched by the addition of $30 \mu \mathrm{L}$ of acetonitrile. After centrifugation, $10 \mu \mathrm{L}$ were injected and analyzed by HPLC-MS. Chromatography for HPLC-MS was performed using a linear gradient of $\mathrm{CH}_{3} \mathrm{CN}$ in $\mathrm{H}_{2} \mathrm{O}$ with $0.1 \%$ formic acid (0-18 min, 5-100\%) at a flow rate of $0.4 \mathrm{~mL} \mathrm{~min}^{-1}$ with UV detection at $540 \mathrm{~nm}$. The activity of YpmL with the different substrates was estimated by the consumption of the substrates compared to the reaction with UCM (2).

Introduction of gene expression construct into S. sp. CB03234 wild-type and mutant strains. To create $y p m L$ expression construct, the $y p m L$ insert was PCR-amplified using $M$. yangpuensis genomic DNA as a template and oligonucleotides ypmL-Xbal-S/ypmL-EcoRI-AS (Table S2). The ypmL DNA fragment was digested and simultaneously cloned into the backbone of pBS18016 ${ }^{\mathrm{S} 5}$ that was previously digested by Xbal and EcoRl and purified by gel extraction, affording pBS23002. The $y p m L$ and the ErmE* promoter was extracted from pBS23002 by Spel and subsequently inserted to $\mathrm{pRT} 801^{\mathrm{S} 6}$ using the same site, to give ypmL-overexpressing vector pBS23003. This construct was introduced into S. sp. CB03234, SB20002, SB20020, CB03234-S through intergeneric conjugation, respectively. ${ }^{S 7, S 8, S 9}$ The recombinant strains S. sp. SB20025, SB20026, SB20027, and SB20028 (Table S1), respectively, were obtained using apramycin selection, and verified by PCR using oligonucleotides PermE-S/ypmL-EcoRI-AS (Table S2).

Fermentation and isolation of the new TNM analogues 14-17. Small-scale fermentation was performed for the production profile analysis of the recombinant strains with parent strains as controls. Fresh spores of Streptomyces strains were cultured in $250 \mathrm{~mL}$ baffled flasks containing $50 \mathrm{~mL}$ of the TSB seed medium. After growth at $28^{\circ} \mathrm{C}$ and $250 \mathrm{rpm}$ for 2 days, $5 \mathrm{~mL}$ of the seed cultures were inoculated into $250-\mathrm{mL}$ flasks containing $50 \mathrm{~mL}$ of the production medium (A: soluble starch $40 \mathrm{~g} / \mathrm{L}$, pharmamedia $20 \mathrm{~g} / \mathrm{L}, \mathrm{CuSO}_{4} \cdot 5 \mathrm{H}_{2} \mathrm{O} 0.2 \mathrm{~g} / \mathrm{L}, \mathrm{Nal} 0.02 \mathrm{~g} / \mathrm{L}, \mathrm{CaCO}_{3} 8 \mathrm{~g} / \mathrm{L}$, pH 7.0, for S. sp. CB03234, SB20002, SB20020, SB20025, SB20026, SB20027; or B: soluble starch $10 \mathrm{~g} / \mathrm{L}$, yeast extract $15 \mathrm{~g} / \mathrm{L}, \mathrm{CuSO}_{4} \cdot 5 \mathrm{H}_{2} \mathrm{O} 0.1 \mathrm{~g} / \mathrm{L}, \mathrm{Nal} 0.005 \mathrm{~g} / \mathrm{L}, \mathrm{CaCO}_{3} 2 \mathrm{~g} / \mathrm{L}, \mathrm{pH} 7.0$, for S. sp. CB03234-S and SB20028) supplemented with 1.5\% (w/v) Dianion HP2MG resin, incubated further for 7 days. ${ }^{\mathrm{S9}, \mathrm{S10}}$ After small-scale fermentations, each culture was centrifuged, and the cell pellets and resins were extracted with $20 \mathrm{~mL}$ acetone twice. Then the extracts were combined, dried in vacuum, and dissolved in $1 \mathrm{~mL} \mathrm{CH}{ }_{3} \mathrm{OH}$. After centrifugation, $10 \mu \mathrm{L}$ were injected and analyzed by HPLC-MS. Chromatography for HPLC-MS was performed using a linear gradient of $\mathrm{CH}_{3} \mathrm{CN}$ in $\mathrm{H}_{2} \mathrm{O}$ with $0.1 \%$ formic acid (0-18 min, 5-100\%) at a flow rate of $0.4 \mathrm{~mL} \mathrm{~min}^{-1}$ with UV detection at $540 \mathrm{~nm}$.

For large-scale fermentation and isolation, 2-L baffled flasks each containing $400 \mathrm{~mL}$ of production medium (A for SB20026, SB20027, B for SB20028) were inoculated with $40 \mathrm{~mL}$ of the seed culture 
and cultured at $28^{\circ} \mathrm{C}$ on a rotary shaker at $250 \mathrm{rpm}$ for 7 days. The cell pellets and resins were collected by centrifuge, and then extracted three times with acetone. The extracts were dried in vacuo and washed three times with $1 \mathrm{~L}$ of EtOAc: $\mathrm{H}_{2} \mathrm{O}(1: 1)$. Then the organic phase was dried in vacuo and subjected to HPLC-MS for analysis or to MPLC for preparation. The crude extract was loaded onto a Biotage SNAP Cartridge KP-C18-HS column (30 g) and fractionated by MPLC with a linear gradient of $5 \% \mathrm{MeOH}$ in $\mathrm{H}_{2} \mathrm{O}$ to $90 \% \mathrm{MeOH}$ in $\mathrm{H}_{2} \mathrm{O}$ at a flow rate of $20 \mathrm{~mL} \mathrm{~min}^{-1}$ with UV detection at $540 \mathrm{~nm}$ and $254 \mathrm{~nm}$. The collected fractions were analyzed by HPLC-MS. The fractions containing the TNM congeners were combined, dried in vacuo, and subjected to Sephadex LH-20 column chromatography eluted with $\mathrm{MeOH}$. The collected fractions were further purified by semipreparative HPLC with UV detection at $540 \mathrm{~nm}$ to afford pure compounds. Fraction for SB20027 was purified RP-HPLC (acetonitrile from $25 \%$ to $100 \%, 3 \mathrm{~mL} / \mathrm{min}$ ) to give 6-hydroxy-TNM E (15) $\left(R_{t}=17.9 \mathrm{~min}\right)$ and 6-hydroxy-TNM B (14) $\left(R_{t}=23.7 \mathrm{~min}\right)$, respectively. 9-Hydroxy-TNM F (16) was eluted on RP-HPLC with gradient elution from $10 \%$ to $70 \%$ acetonitrile over $30 \mathrm{~min}$ at a flow rate of $3 \mathrm{~mL} / \mathrm{min}\left(\mathrm{R}_{t}=21.2 \mathrm{~min}\right)$ from fractions of SB20026. Purification for 9-hydroxy-TNM D (17) was completed on RP-HPLC with gradient elution from $10 \%$ to $70 \%$ acetonitrile over $30 \mathrm{~min}$ at a flow rate of $3 \mathrm{~mL} / \mathrm{min}\left(R_{t}=22.7 \mathrm{~min}\right)$ from fractions of SB20028. For SB20027, $5 \mathrm{mg}$ of 14 and $3 \mathrm{mg}$ of 15 were isolated from 10-L fermentation. For SB20026, $8 \mathrm{mg}$ of 16 were isolated from 14-L fermentation. For SB20028, $3 \mathrm{mg}$ of 17 were isolated from 10-L fermentation.

\section{Physicochemical properties of the new TNM analogues 14-17.}

6-hydroxy-TNM B (14): purple powder; [a] ${ }^{20}{ }_{D}+600$ (c 0.001, MeOH); UV (MeOH) $\lambda_{\max }(\log \varepsilon) 232$ (4.27) nm, $260 \mathrm{~nm}$ (shoulder), 408 (3.07) nm, 543 (3.92) nm, $587 \mathrm{~nm}$ (shoulder); ${ }^{1} \mathrm{H}$ and ${ }^{13} \mathrm{C}$ NMR (acetone- $d_{6}$ ) data, see Table S3; HR-ESI-MS $\mathrm{m} / z$ 508.1040 [M-H] (calcd for $\mathrm{C}_{29} \mathrm{H}_{19} \mathrm{NO}_{8}$, 508.1038).

6-hydroxy-TNM E (15): purple powder; [a] ${ }^{20} \mathrm{D}+700$ (c 0.001, MeOH); UV (MeOH) $\lambda_{\max }(\log \varepsilon) 233$ (4.31) nm, $258 \mathrm{~nm}$ (shoulder), 403 (2.92) nm, 545 (3.87) nm, $583 \mathrm{~nm}$ (shoulder); ${ }^{1} \mathrm{H}$ and ${ }^{13} \mathrm{C}$ NMR (acetone- $d_{6}$ ) data, see Table S3; HR-ESI-MS m/z 542.1098 [M-H] (calcd for $\mathrm{C}_{29} \mathrm{H}_{21} \mathrm{NO}_{10}$, 542.1093).

9-hydroxy-TNM F (16): purple powder; [a] ${ }^{20} \mathrm{D}+1100$ (c 0.001, MeOH); UV (MeOH) $\lambda_{\max }(\log \varepsilon)$ 230 (4.42) nm, $281 \mathrm{~nm}$ (shoulder), 410 (3.22) nm, 543 (3.94) nm, $582 \mathrm{~nm}$ (shoulder); ${ }^{1} \mathrm{H}$ and ${ }^{13} \mathrm{C}$ NMR (acetone- $d_{6}$ ) data, see Table S3; HR-ESI-MS m/z 558.1049 [M-H] (calcd for $\mathrm{C}_{29} \mathrm{H}_{21} \mathrm{NO}_{11}$, 558.1042).

9-hydroxy-TNM D (17): blue powder; [a] ${ }^{20} \mathrm{D}+600$ (c 0.001, MeOH); UV (MeOH) $\lambda_{\max }(\log \varepsilon) 228$ (4.51) nm, $262 \mathrm{~nm}$ (shoulder), 420 (3.32) nm, 548 (4.01) nm, $573 \mathrm{~nm}$ (shoulder); ${ }^{1} \mathrm{H}$ and ${ }^{13} \mathrm{C}$ NMR (acetone- $d_{6}$ ) data, see Table S3; HR-ESI-MS $m / z 588.1153[\mathrm{M}-\mathrm{H}]$ ] (calcd for $\mathrm{C}_{30} \mathrm{H}_{23} \mathrm{NO}_{12}$, 588.1148).

Cytotoxicity assay of 14-17. The $\mathrm{IC}_{50} \mathrm{~S}$ of 14-17 against selected human cancer cell lines, including melanoma (SK-MEL-5), breast (MDA-MB-231 and SKBR-3), glioblastoma (SF-295), and non-small cell lung cancer ( $\mathrm{NCl}-\mathrm{H} 226)$, with TNM $A(3)$ and $D(11)$ as controls, were determined as follows. Suspended cultures of cells were diluted to a concentration of $5 \times 10^{4}$ cells per mL in RPMI 1640 medium supplemented with $10 \%$ fetal bovine serum, $100 \mu \mathrm{g}$ per mL of streptomycin, and $100 \mathrm{U}$ per $\mathrm{mL}$ of penicillin. The suspended cultures were dispensed into 96well plates $\left(150 \mu \mathrm{L}\right.$ per well), and the plates were incubated for $24 \mathrm{~h}$ at $37^{\circ} \mathrm{C}$ in an atmosphere of $5 \% \mathrm{CO}_{2}, 95 \%$ air, and $100 \%$ humidity. Followed by adding $50 \mu \mathrm{L}$ serial dilutions of drugs $(1 \mu \mathrm{L}$ in DMSO with final concentration ranging from 0 to $1000 \mathrm{nM}$ ), plates were incubated under the above conditions for $72 \mathrm{~h}$. Finally, $20 \mu \mathrm{L}$ of CellTiter $96^{\circledR}$ AQueous One Solution Reagent (Promega) was added to the plates and incubation continued as above for 30 to $60 \mathrm{~min}$. The 
absorbance at $490 \mathrm{~nm}$ was recorded using an ELISA plate reader. Each point represents the mean \pm SD of two or three replicates, and the $\mathrm{IC}_{50}$ was determined by computerized curve fitting using GraphPad Prism (Figure S10).

Plasmid Relaxation Assay. Compounds 14-17 were assayed for their efficacy to relax supercoiled plasmid DNA by generating single- and double-strand DNA breaks, as previously described (Figure S11A). ${ }^{S 11}$ Briefly, assays were performed in $20 \mu \mathrm{L}$ (total volume) of Dulbecco's phosphate buffered saline $(\mathrm{pH} 7.4)$ with $5 \%$ DMSO, containing $0.8 \mu \mathrm{g}(25 \mathrm{nM}$ plasmid, $120 \mu \mathrm{M}$ base pair) of pUC19 (NEB), and varying concentrations of compounds. The assays were performed in triplicate in the presence and absence of $1 \mathrm{mM}$ reduced glutathione. The reactions were incubated at $37^{\circ} \mathrm{C}$ for $24 \mathrm{~h}$, after which $5 \mu \mathrm{L}$ of loading dye was added and samples were analyzed by electrophoresis on a $1 \%$ agarose gel containing SYBR Green I nucleic acid gel stain (Thermo Fisher). Gel electrophoresis was carried out in TAE buffer at $100 \mathrm{~V}$ for $1 \mathrm{~h}$. The relative activity was determined by quantifying the intensity of bands corresponding to supercoiled plasmid (form I, Figure S11B) normalized to DMSO treated controls. Band intensity was quantified using ImageJ software. ${ }^{S 12}$ The quantified band intensities were plotted using GraphPad Prism (Figure S11C). 
Table S1. Strains and plasmids used in this study

\begin{tabular}{|c|c|c|}
\hline Strain & Genotype and description & Reference/Source \\
\hline E. coli DH5a & E. coli host for general cloning & Life Technologies \\
\hline E. coli BL21 (DE3) & E. coli host for protein production & Life Technologies \\
\hline $\begin{array}{l}\text { Micromonospora } \\
\text { yangpuensis }\end{array}$ & Wild-type YPM A producer & S1 \\
\hline $\begin{array}{l}\text { Streptomyces } \\
\text { uncialis }\end{array}$ & Wild-type UCM producer & S13 \\
\hline $\begin{array}{l}\text { Streptomyces sp. } \\
\text { CB03234 }\end{array}$ & Wild-type TNM A producer & S7 \\
\hline S. sp. SB20002 & The $\Delta t n m H$ mutant strain of $S . s p$. CB03234 & S7 \\
\hline S. sp. SB20020 & The $\Delta t n m L$ mutant strain of $S$. sp. CB03234 & S8 \\
\hline S. sp. CB03234-S & $\begin{array}{l}\text { High TNM D producer generated from S. sp. } \\
\text { CB03234 through streptomycin-mediated } \\
\text { ribosome engineering }\end{array}$ & s9 \\
\hline S. sp. SB20025 & $\begin{array}{l}\text { S. sp. CB03234 harboring plasmid pBS23003 } \\
\text { expressing ypmL }\end{array}$ & This study \\
\hline S. sp. SB20026 & $\begin{array}{l}\text { S. sp. SB20002 harboring plasmid pBS23003 } \\
\text { expressing ypmL }\end{array}$ & This study \\
\hline S. sp. SB20027 & $\begin{array}{l}\text { S. sp. SB20020 harboring plasmid pBS23003 } \\
\text { expressing ypmL }\end{array}$ & This study \\
\hline S. sp. SB20028 & $\begin{array}{l}\text { S. sp. CB03234-S harboring plasmid pBS23003 } \\
\text { expressing ypmL }\end{array}$ & This study \\
\hline \multicolumn{3}{|l|}{ Plasmid } \\
\hline pBS3080 & $\begin{array}{l}\text { pRSFDuet-1 derived plasmid containing a BsmFI } \\
\text { site for ligation-independent cloning (LIC) and } \\
\text { encodes a TEV }\end{array}$ & S2 \\
\hline pBS23001 & $\begin{array}{l}\mathrm{pET} 28 \mathrm{a} \text { harboring the full length } y p m L \text {, used for } \\
\text { protein production }\end{array}$ & This study \\
\hline pBS18016 & Plasmid containing $u \mathrm{cmM}$ with $E r m E^{*}$ promoter & S5 \\
\hline pBS23002 & ypmL cloned into pBS18016 backbone & This study \\
\hline pRT801 & $\begin{array}{l}\varphi \mathrm{BT} 1 \text {-based integrative cloning vector, apramycin } \\
\text { resistance }\end{array}$ & S6 \\
\hline pBS23003 & $\begin{array}{l}\text { pRT801 based plasmid containing ypmL gene } \\
\text { with ErmE* promoter, used for ypmL expression }\end{array}$ & This study \\
\hline
\end{tabular}


Table S2. Oligonucleotides used in this study

\begin{tabular}{lll}
\hline Primer & Nucleotide Sequence (5'-3') & Function \\
YpmL-F & AAAACCTCTATTTCCAGTCGATGGGTGAATCGCG & ypmL amplification \\
& GAGATATCC & \\
YpmL-R & TACTTACTTAAATGTTACCAGGTGACGGGCAGC & $y p m L$ amplification \\
ypmL-Xbal-S & ATATGTCTAGACTGAACAGAGAAAGGTCGGTGGG & $y p m L$ amplification \\
ypmL-EcoRI-AS & GATAGGAATTCCCTGCAGGTCACCAGGTGACGGG & ypmL amplification \\
& CAGCC & $\begin{array}{l}\text { and exconjugant } \\
\text { verification }\end{array}$ \\
PermE-S & GTGGCACCGCGATGCTGTTG & Exconjugant \\
& & verification \\
\hline
\end{tabular}


Table S3. NMR spectroscopic data $\left({ }^{1} \mathrm{H}\right.$ at $600 \mathrm{MHz}$ and ${ }^{13} \mathrm{C}$ at $150 \mathrm{MHz}$, acetone- $\left.d_{6}\right)$ for the new TNM analogues 14-17

\begin{tabular}{|c|c|c|c|c|c|c|c|c|}
\hline \multirow[b]{2}{*}{ Position } & \multicolumn{2}{|c|}{ 6-Hydroxy-TNM B (14) } & \multicolumn{2}{|c|}{ 6-Hydroxy-TNM E (15) } & \multicolumn{2}{|c|}{ 9-Hydroxy-TNM F (16) } & \multicolumn{2}{|c|}{ 9-Hydroxy-TNM D (17) } \\
\hline & $\delta_{C}$, type & $\delta_{\mathrm{H}},(\mathrm{J}$ in $\mathrm{Hz})$ & $\delta_{C}$, type & $\delta_{\mathrm{H}},(\mathrm{J}$ in $\mathrm{Hz})$ & $\delta_{c}$, type & $\delta_{\mathrm{H}},(\mathrm{J}$ in $\mathrm{Hz})$ & $\delta_{C}$, type & $\delta_{\mathrm{H}},(\mathrm{J}$ in $\mathrm{Hz})$ \\
\hline 1 & & $10.21, \mathrm{~d}(4.2)$ & & $10.22, d(5.0)$ & & $10.14, \mathrm{~d}(4.8)$ & & $9.90, d(5.0)$ \\
\hline 2 & $145.0, \mathrm{C}$ & & $145.6, \mathrm{C}$ & & $145.6, \mathrm{C}$ & & $145.9, \mathrm{C}$ & \\
\hline 3 & $112.4, \mathrm{C}$ & & $111.4, \mathrm{C}$ & & 111.7, C & & 111.7, C & \\
\hline 4 & $192.4, \mathrm{C}$ & & 192.2, C & & 183.0, C & & $188.4, \mathrm{C}$ & \\
\hline 5 & 116.9. C & & $117.0, \mathrm{C}$ & & 138.2, C & & 114.3, C & \\
\hline 6 & $163.1, \mathrm{C}$ & & 163.0, C & & $108.8, \mathrm{CH}$ & $7.31, d(2.4)$ & $150.3, \mathrm{C}$ & \\
\hline 7 & 123.6, $\mathrm{CH}$ & $7.30, \mathrm{dd}(7.4,1.7)$ & 123.3, $\mathrm{CH}$ & 7.27, dd $(7.8,1.4)$ & $166.8, \mathrm{C}$ & & 159.1, C & \\
\hline 8 & $138.1, \mathrm{CH}$ & $7.81, \mathrm{t}(7.4)$ & $138.0, \mathrm{CH}$ & $7.80, \mathrm{t}(7.8)$ & $107.8, \mathrm{CH}$ & $6.62, \mathrm{~d}(2.4)$ & 106.7, $\mathrm{CH}$ & $6.82, \mathrm{~s}$ \\
\hline 9 & $119.8, \mathrm{CH}$ & $7.83, \mathrm{dd}(7.4,1.7)$ & 119.6, CH & 7.82, dd $(7.8,1.4)$ & 166.1, C & & $160.8, \mathrm{C}$ & \\
\hline 10 & 136.0, C & & 136.2, C & & 110.6, C & & 106.9, C & \\
\hline 11 & 183.5, C & & 183.0, C & & 190.1, C & & 188.2, C & \\
\hline 12 & 114.1, C & & $113.5, \mathrm{C}$ & & 113.3, C & & 113.7, C & \\
\hline 13 & $156.8, \mathrm{C}$ & & $156.8, \mathrm{C}$ & & 156.3, C & & 156.2, C & \\
\hline 14 & $131.3, \mathrm{CH}$ & $8.62, \mathrm{~s}$ & 132.2, $\mathrm{CH}$ & $8.69, \mathrm{~s}$ & $132.4, \mathrm{CH}$ & $8.65, \mathrm{~s}$ & $132.8, \mathrm{CH}$ & $8.68, \mathrm{~s}$ \\
\hline 15 & $136.2, \mathrm{C}$ & & 138.3, C & & 137.2, C & & 136.6, C & \\
\hline 16 & $67.7, \mathrm{C}$ & & $68.2, \mathrm{C}$ & & $68.2, \mathrm{C}$ & & $68.2, \mathrm{C}$ & \\
\hline 17 & $66.5, \mathrm{CH}$ & 5.05, brs & $64.9, \mathrm{CH}$ & $6.30, \mathrm{~s}$ & $65.0, \mathrm{CH}$ & $6.28, s$ & $65.0, \mathrm{CH}$ & $6.29, d(5.3)$ \\
\hline 18 & 101.0, C & & 103.1, C & & 103.1, C & & 103.1, C & \\
\hline 19 & $91.9, \mathrm{C}$ & & 92.6, C & & $92.6, \mathrm{C}$ & & $92.7, \mathrm{C}$ & \\
\hline 20 & $124.8, \mathrm{CH}$ & $6.14, d(10.0)$ & $124.9, \mathrm{CH}$ & $6.05, d(10.0)$ & $124.8, \mathrm{CH}$ & $6.04, d(10.0)$ & $125.0, \mathrm{CH}$ & $6.06, d(10.1)$ \\
\hline 21 & $124.2, \mathrm{CH}$ & $6.04, d(10.0)$ & 123.6, $\mathrm{CH}$ & $5.93, d(10.0)$ & 123.6, $\mathrm{CH}$ & $5.92, d(10.0)$ & 123.6, $\mathrm{CH}$ & $5.95, d(10.1)$ \\
\hline 22 & 89.9, C & & $90.0, \mathrm{C}$ & & $90.0, \mathrm{C}$ & & $90.1, \mathrm{C}$ & \\
\hline 23 & $98.7, \mathrm{C}$ & & $98.5, \mathrm{C}$ & & $98.5, \mathrm{C}$ & & $98.3, \mathrm{C}$ & \\
\hline 24 & 47.2, $\mathrm{CH}$ & $4.99, d(4.2)$ & $45.5, \mathrm{CH}$ & $5.38, d(5.0)$ & $45.5, \mathrm{CH}$ & $5.36, d(4.8)$ & $45.6, \mathrm{CH}$ & $5.41, d(5.0)$ \\
\hline 25 & $76.7, \mathrm{C}$ & & $80.0, \mathrm{C}$ & & $79.9, \mathrm{C}$ & & $80.2, \mathrm{C}$ & \\
\hline 26 & $149.1, \mathrm{C}$ & & $77.5, \mathrm{C}$ & & $77.4, \mathrm{C}$ & & $77.4, \mathrm{C}$ & \\
\hline 27 & 17.3, $\mathrm{CH}_{3}$ & 2.42, d (1.4) & $25.8, \mathrm{CH}_{3}$ & $1.65, \mathrm{~s}$ & 25.8, $\mathrm{CH}_{3}$ & $1.65, \mathrm{~s}$ & 25.8, $\mathrm{CH}_{3}$ & $1.66, \mathrm{~s}$ \\
\hline 28 & $122.2, \mathrm{CH}$ & $6.53, \mathrm{~s}$ & $76.1, \mathrm{CH}$ & $4.42, \mathrm{~s}$ & $76.1, \mathrm{CH}$ & $4.42, \mathrm{~s}$ & $76.1, \mathrm{CH}$ & $4.42, \mathrm{~s}$ \\
\hline 29 & 166.7, C & & $173.9, \mathrm{C}$ & & $173.9, \mathrm{C}$ & & $173.9, \mathrm{C}$ & \\
\hline $6-\mathrm{OH}$ & & 12.17, brs & & 12.17, brs & & & & 13.65, brs \\
\hline $9-\mathrm{OH}$ & & & & & & 12.35, brs & & 12.80, brs \\
\hline $13-\mathrm{OH}$ & & 12.50, brs & & 12.52, brs & & 12.61 , brs & & 12.69, brs \\
\hline 30 & 51.6, $\mathrm{CH}_{3}$ & $3.71, \mathrm{~s}$ & $52.6, \mathrm{CH}_{3}$ & $3.77, \mathrm{~s}$ & $52.6, \mathrm{CH}_{3}$ & $3.77, \mathrm{~s}$ & 52.6, $\mathrm{CH}_{3}$ & $3.77, \mathrm{~s}$ \\
\hline 7-OMe & & & & & & & $57.1, \mathrm{CH}_{3}$ & $4.04, \mathrm{~s}$ \\
\hline
\end{tabular}


Figure S1. Characterization of YpmL as a cytochrome P450. (A) SDS-PAGE analysis of purified YpmL. The molecular weight (MW) marker used is the Unstained Protein Ladder (NEB). The calculated expected MW of YpmL is $46.2 \mathrm{kDa}$. (B) Size-exclusion chromatography of YpmL. YpmL (red circle) eluted at a retention time of $58.3 \mathrm{~mL}$, correlating to a MW of $48.6 \mathrm{kDa}$. (C) The ferrous- $\mathrm{CO}$ difference spectrum of $\mathrm{YpmL}$ yielding a characteristic absorbance maximum at 450 $\mathrm{nm}$. Spectrum of P450 after sodium dithionite reduction (Ferrous), spectrum of P450 after sodium dithionite reduction and carbon monoxide incubation (Ferrous-CO), and Ferrous-CO versus Ferrous difference spectrum are traced in black, grey and red, respectively.

A $\quad \mathrm{kDa} \mathrm{MW} \quad \mathrm{YpmL}$
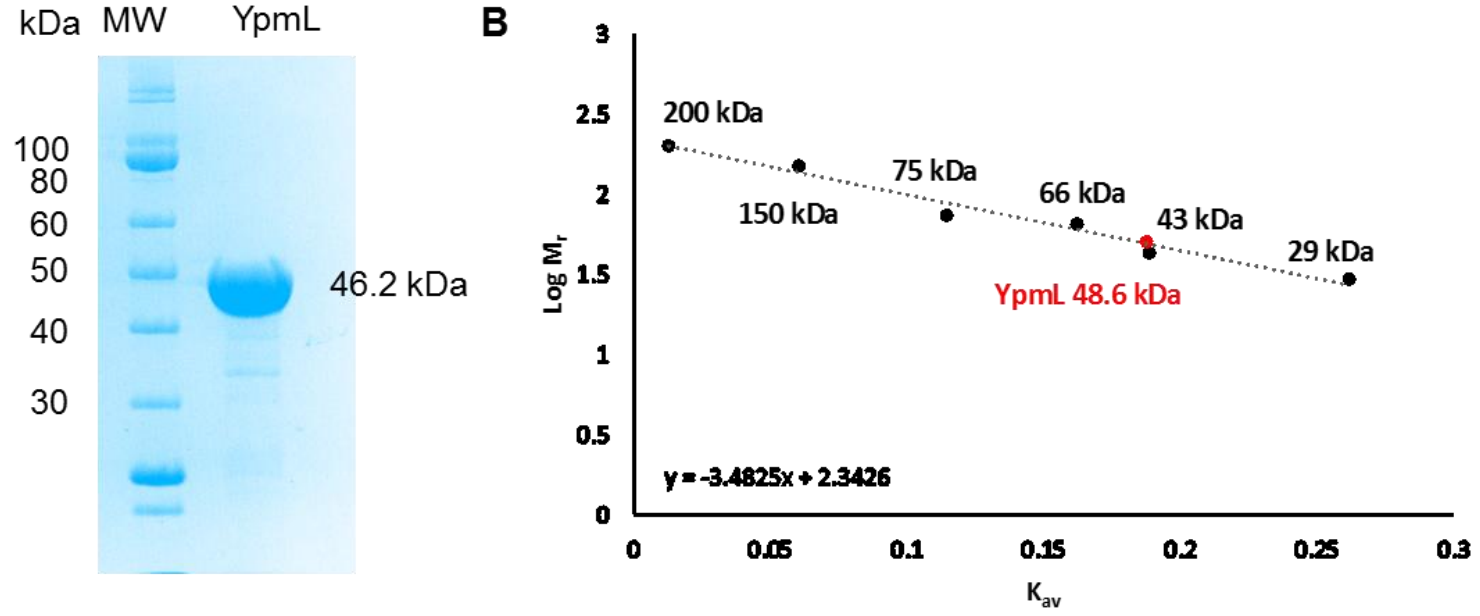

C

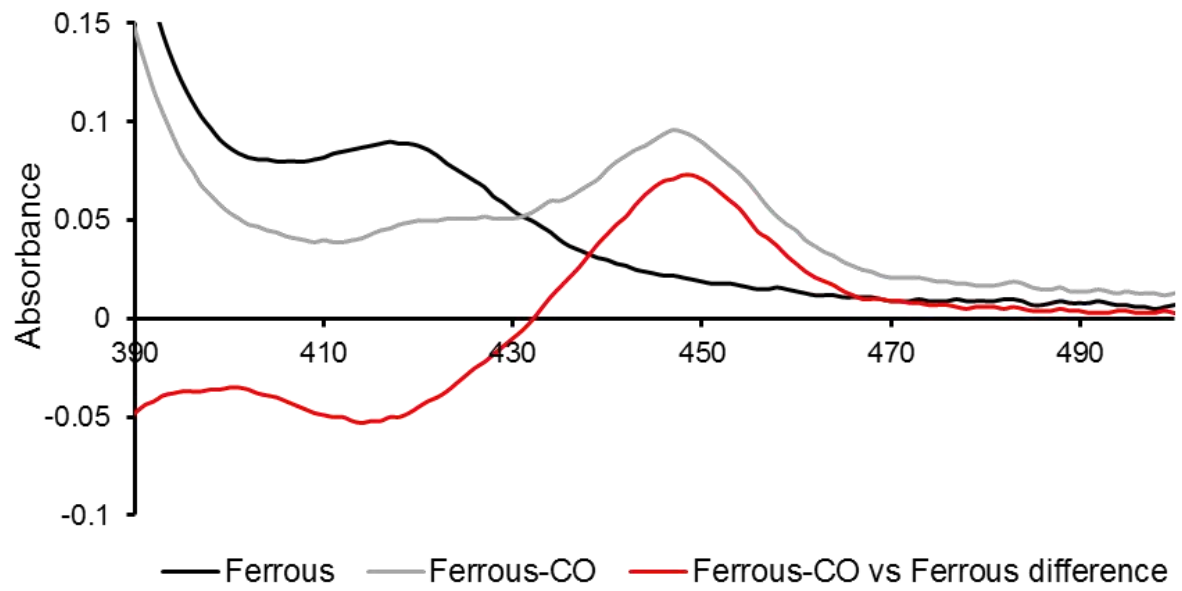


Figure S2. HR-ESI-MS spectrum confirming the identity of the product as YPM A (4), for the YpmL-catalyzed hydroxylation using UCM (2) as substrates in vitro. HPLC chromatogram with UV detection at $540 \mathrm{~nm}$ are shown in Figure $2 \mathrm{C}$, panel iii. Calculated $m / z[\mathrm{M}-\mathrm{H}]^{-}$for $4\left(\mathrm{C}_{26} \mathrm{H}_{17} \mathrm{NO}_{7}\right)$ is 454.0932 .

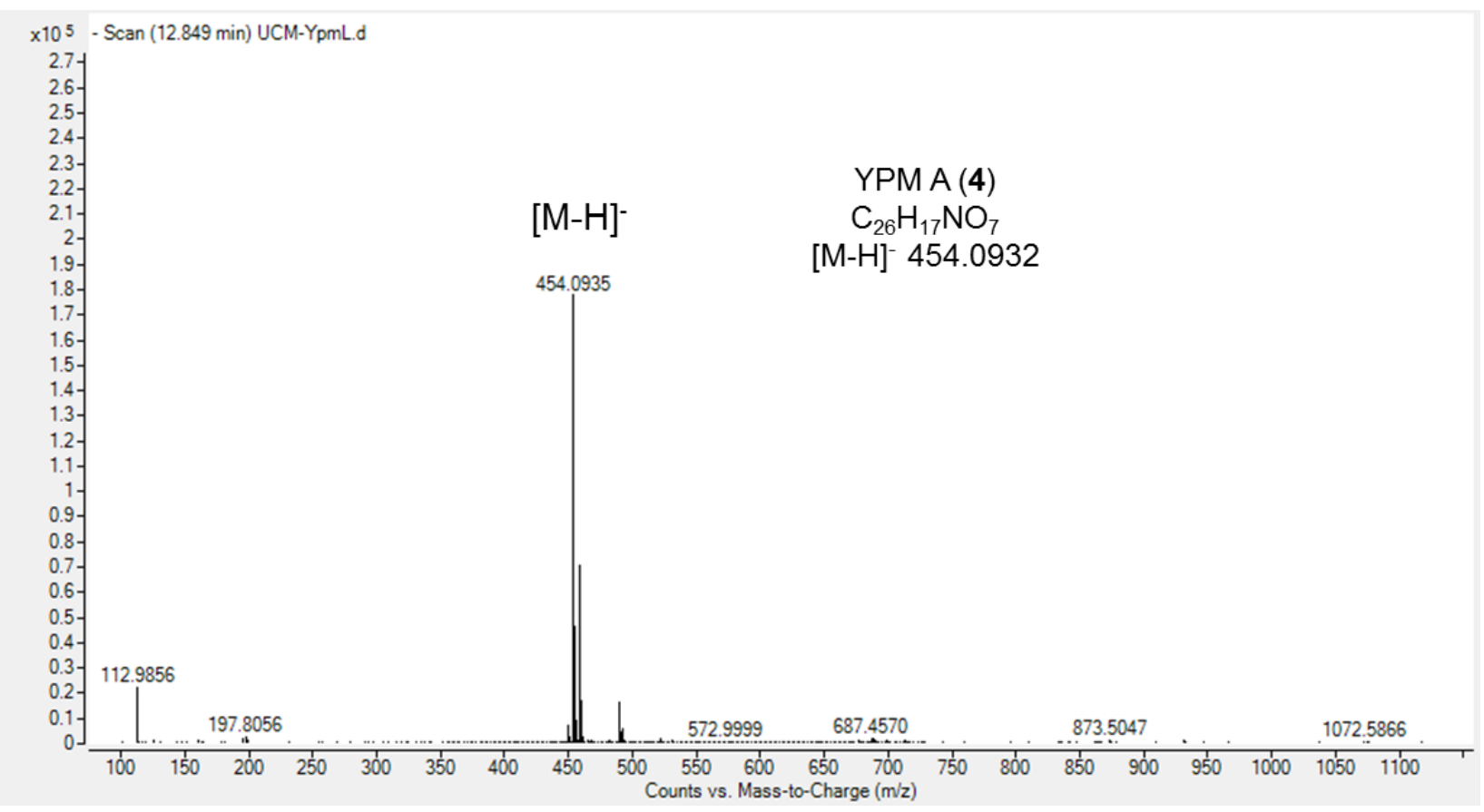


Figure S3. HR-ESI-MS spectra of the products of in vitro YpmL-catalyzed hydroxylation with 7, $8,9,10,11$ and 3 as substrates, respectively. HPLC chromatograms of the same analyses with UV detection at $540 \mathrm{~nm}$ are shown in Figure 2D, panels ii, iv, 2E, panels ii, iv, and 2F, panels ii, iv, respectively. (A) HR-ESI-MS spectrum of $14\left(\mathrm{C}_{29} \mathrm{H}_{19} \mathrm{NO}_{8}\right.$, calculated for [M-H]', 508.1038) for the hydroxylated product of 7; (B) HR-ESI-MS spectrum of $15\left(\mathrm{C}_{29} \mathrm{H}_{21} \mathrm{NO}_{10}\right.$, calculated for [M-H]', 542.1093) for the hydroxylated product of 8; (C) HR-ESI-MS spectrum of $16\left(\mathrm{C}_{29} \mathrm{H}_{21} \mathrm{NO}_{11}\right.$, calculated for [M-H], 558.1042) for the hydroxylated product of 9; (D) HR-ESI-MS spectrum of $18\left(\mathrm{C}_{29} \mathrm{H}_{21} \mathrm{NO}_{10}\right.$, calculated for [M-H], 574.0991$)$ for the hydroxylated product of 10; (E) HR-ESIMS spectrum of $17\left(\mathrm{C}_{30} \mathrm{H}_{23} \mathrm{NO}_{12}\right.$, calculated for [M-H]', 588.1148) for the hydroxylated product of 11; (F) HR-ESI-MS spectrum of $19\left(\mathrm{C}_{27} \mathrm{H}_{19} \mathrm{NO}_{10}\right.$, calculated for $\left.[\mathrm{M}-\mathrm{H}]-500.0987\right)$ for the hydroxylated product of 3 .

A

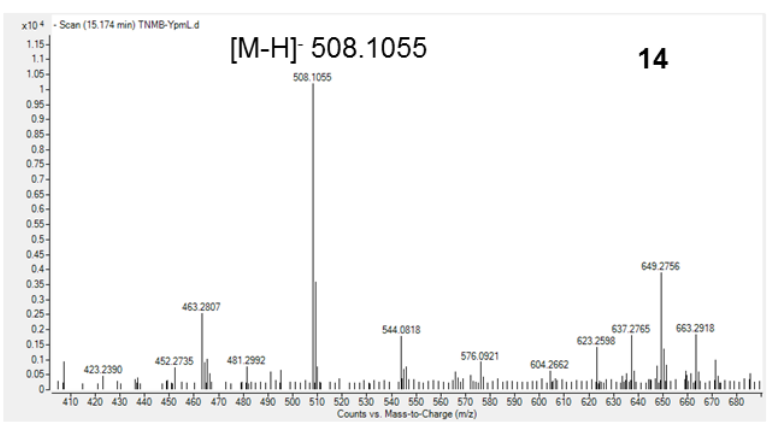

C

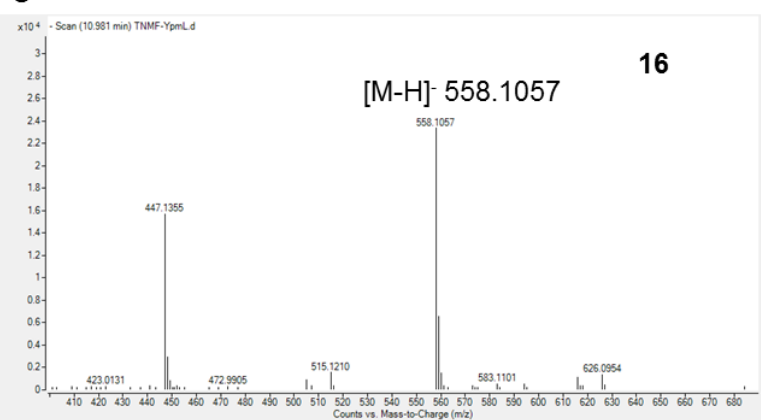

E

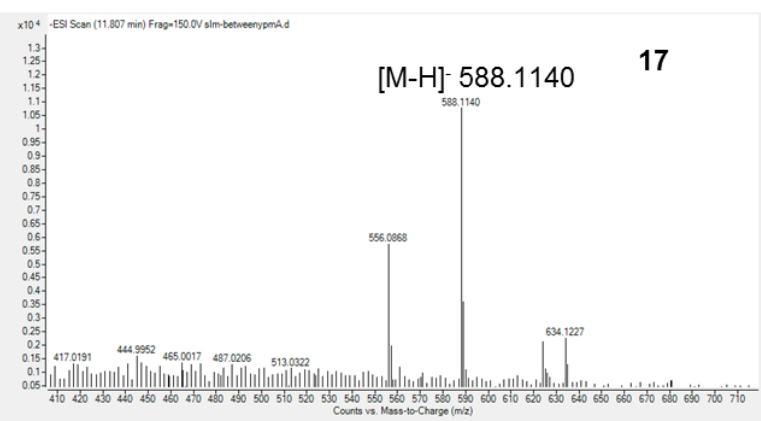

B

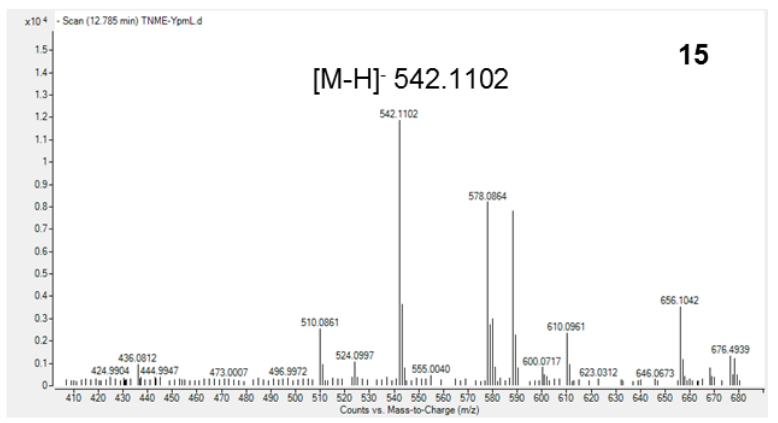

D

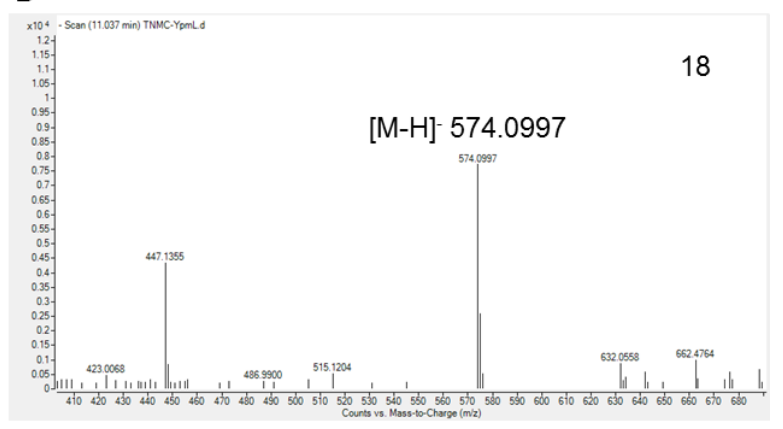

F

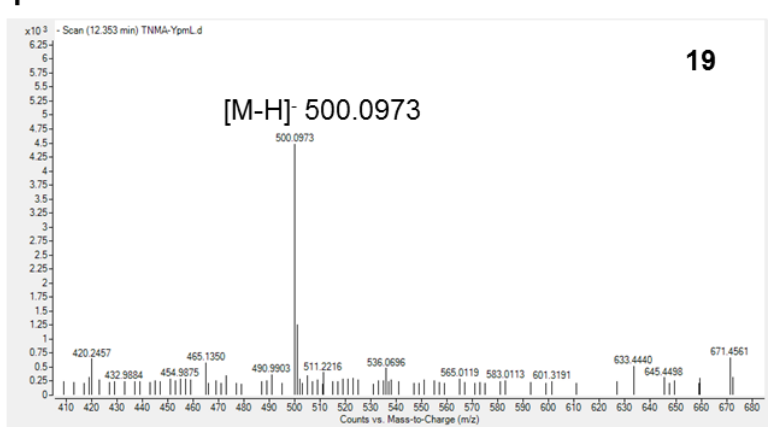


Figure S4. HPLC-MS analysis of crude extracts of SB20025 (ii) with wild-type CB03234 (i) as a control.

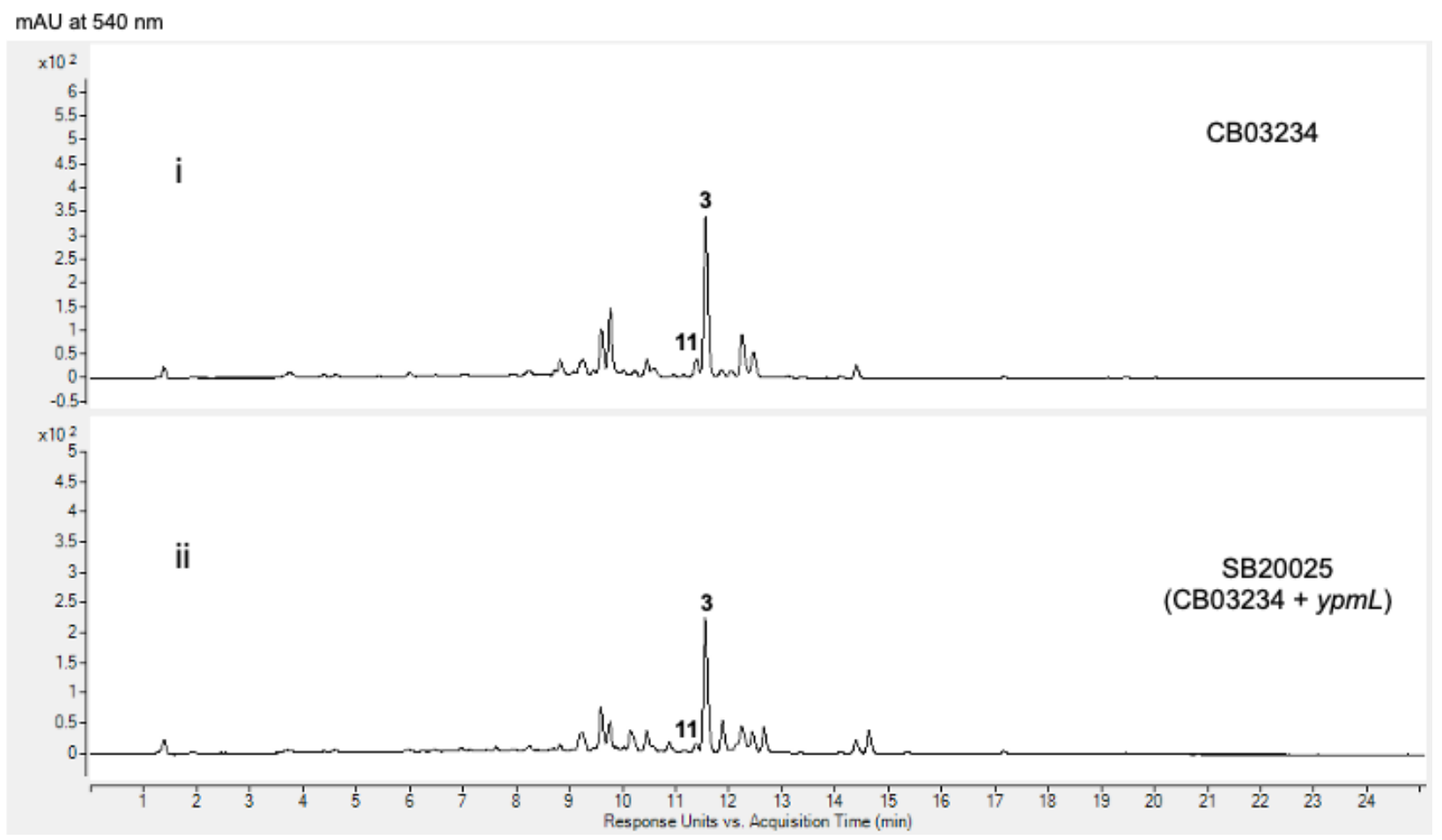


Figure S5A HR-ESI-MS spectrum of 14

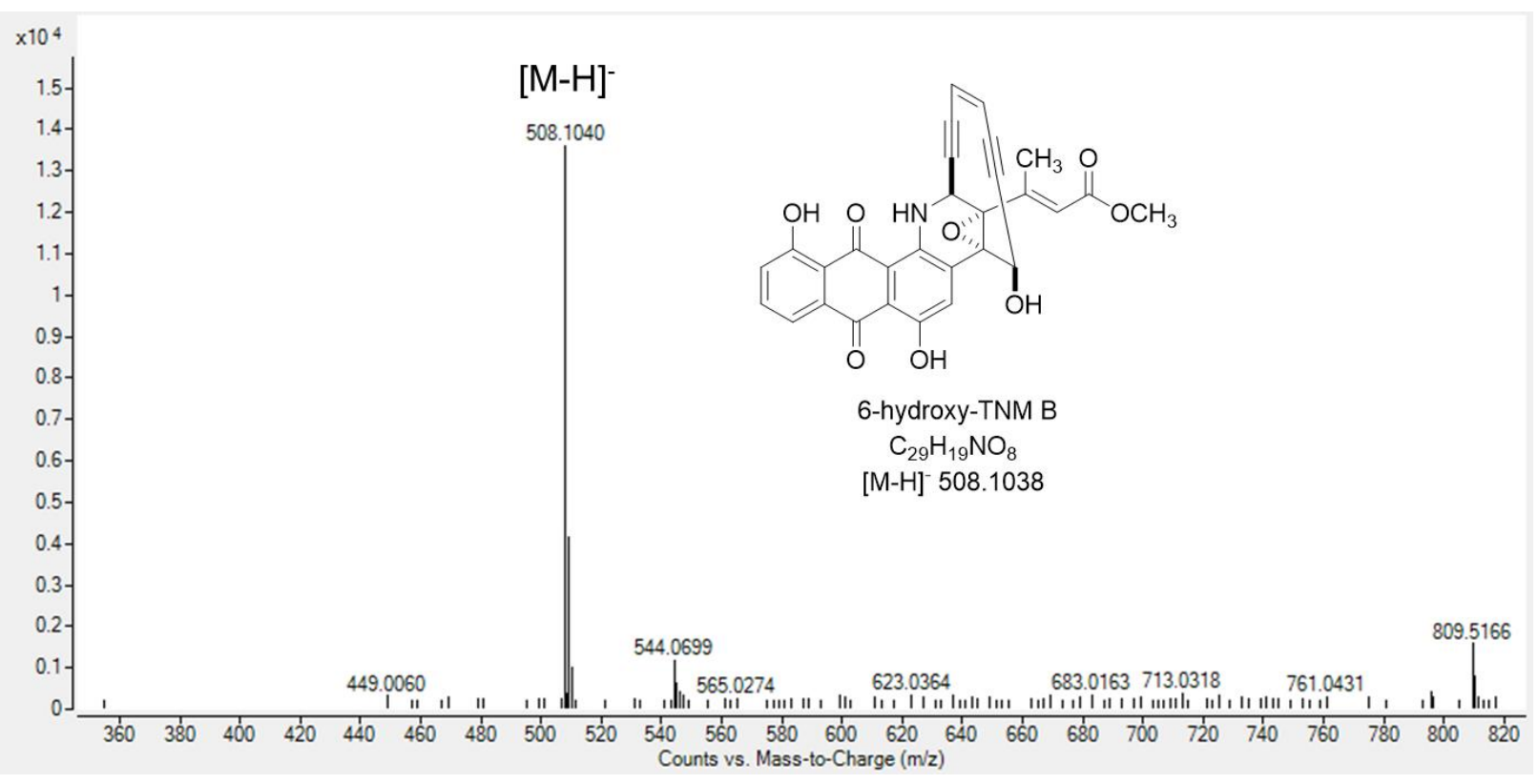


Figure S5B $\quad{ }^{1} \mathrm{H}$ NMR spectrum of $14\left(600 \mathrm{MHz}\right.$, acetone- $\left.d_{6}\right)$

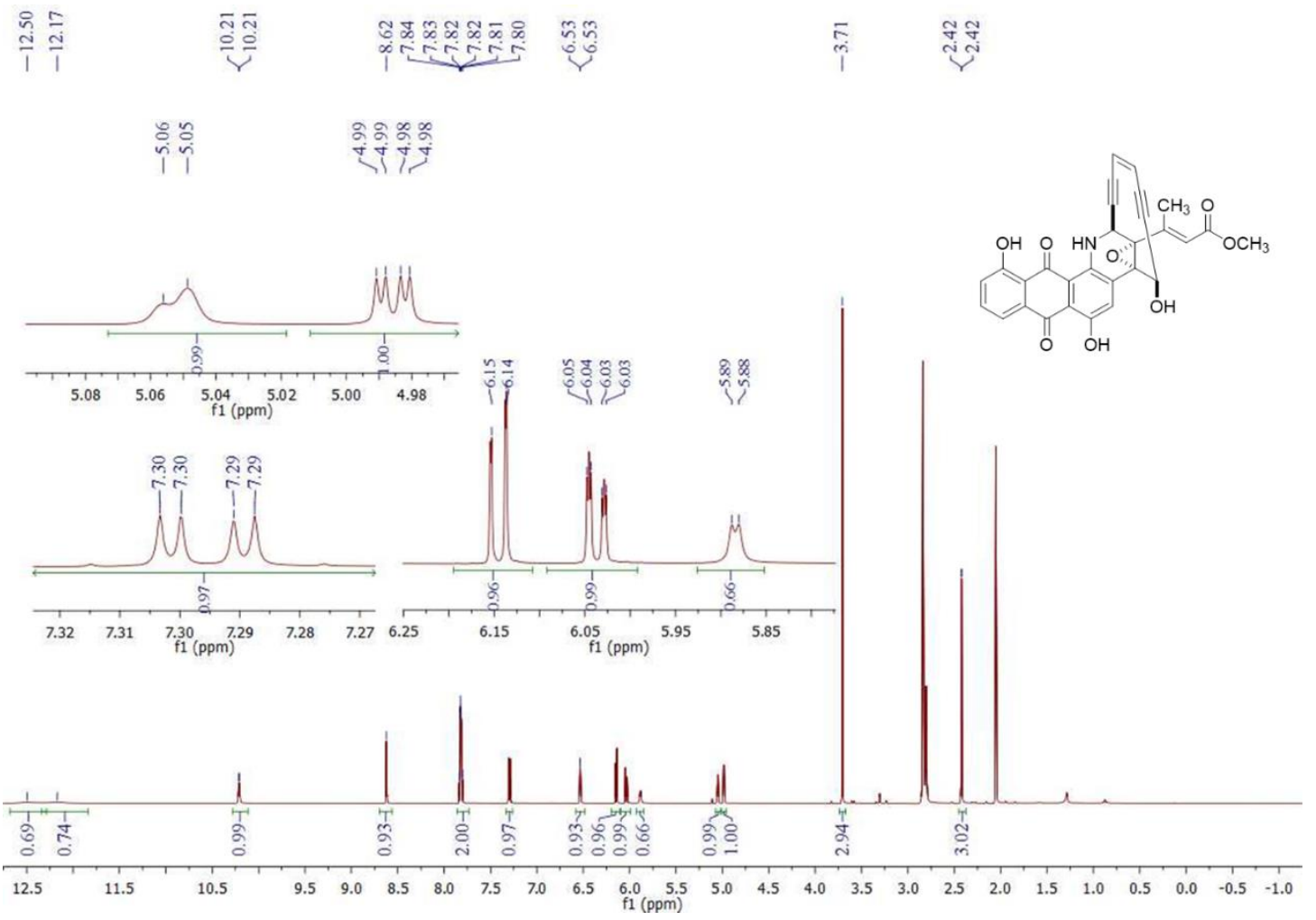

Figure S5C ${ }^{13} \mathrm{C}$ NMR spectrum of $14\left(150 \mathrm{MHz}\right.$, acetone- $\left.d_{6}\right)$

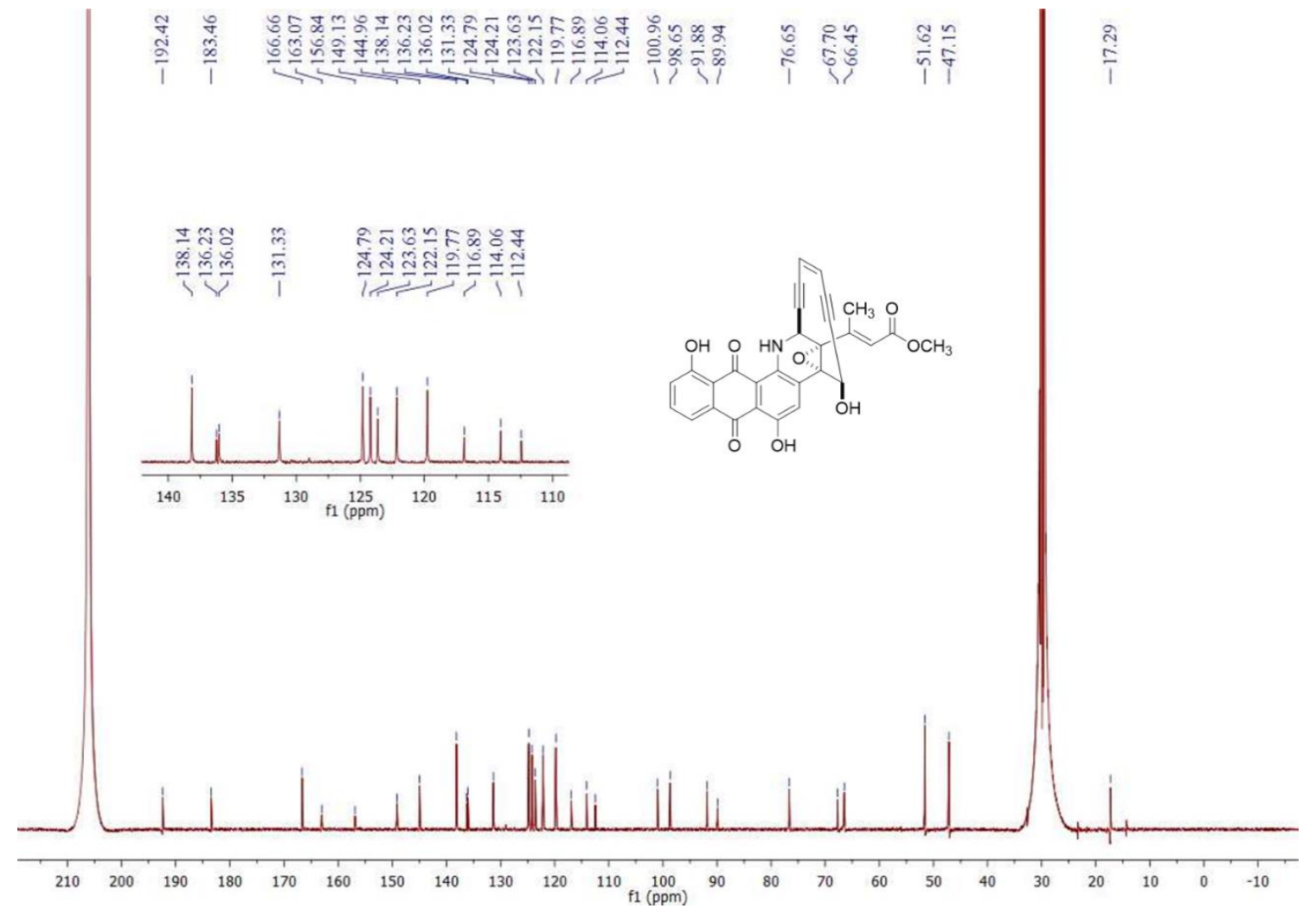


Figure S5D $\quad{ }^{1} \mathrm{H}-{ }^{1} \mathrm{H}$ COSY spectrum of $\mathbf{1 4}$ (acetone- $d_{6}$ )

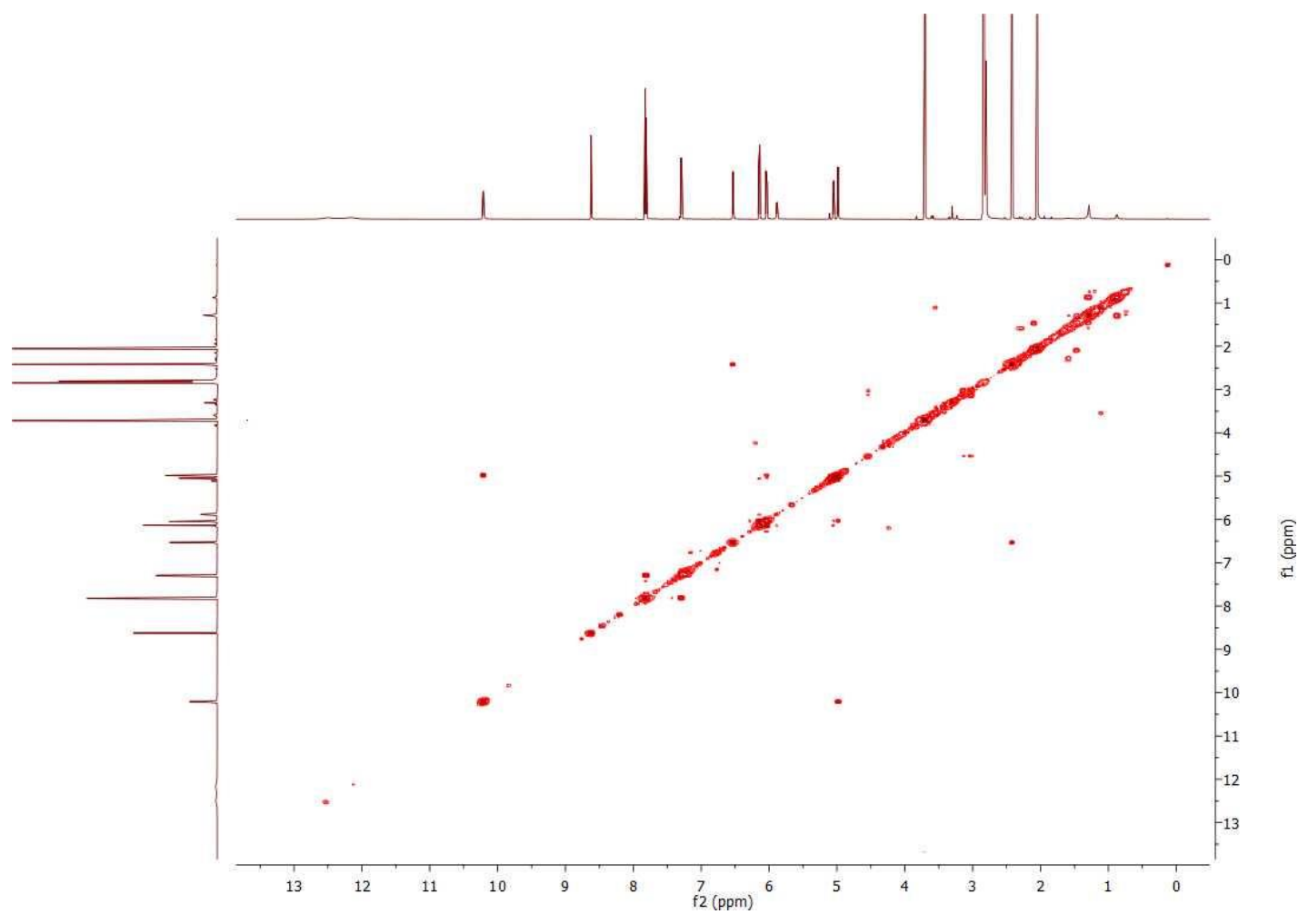

Figure S5E HSQC spectrum of $\mathbf{1 4}$ (acetone- $d_{6}$ )

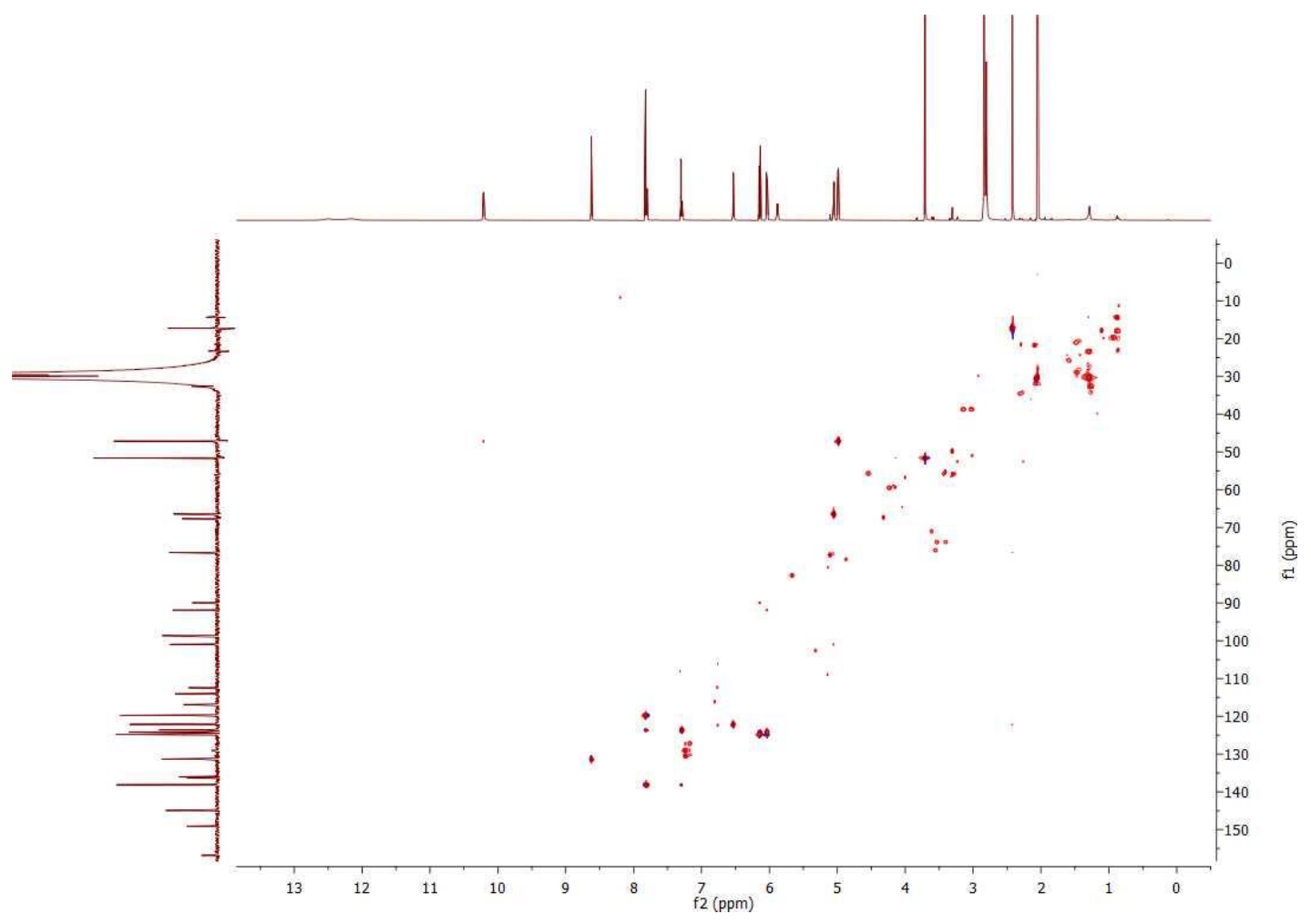


Figure S5F HMBC spectrum of $\mathbf{1 4}$ (acetone- $d_{6}$ )

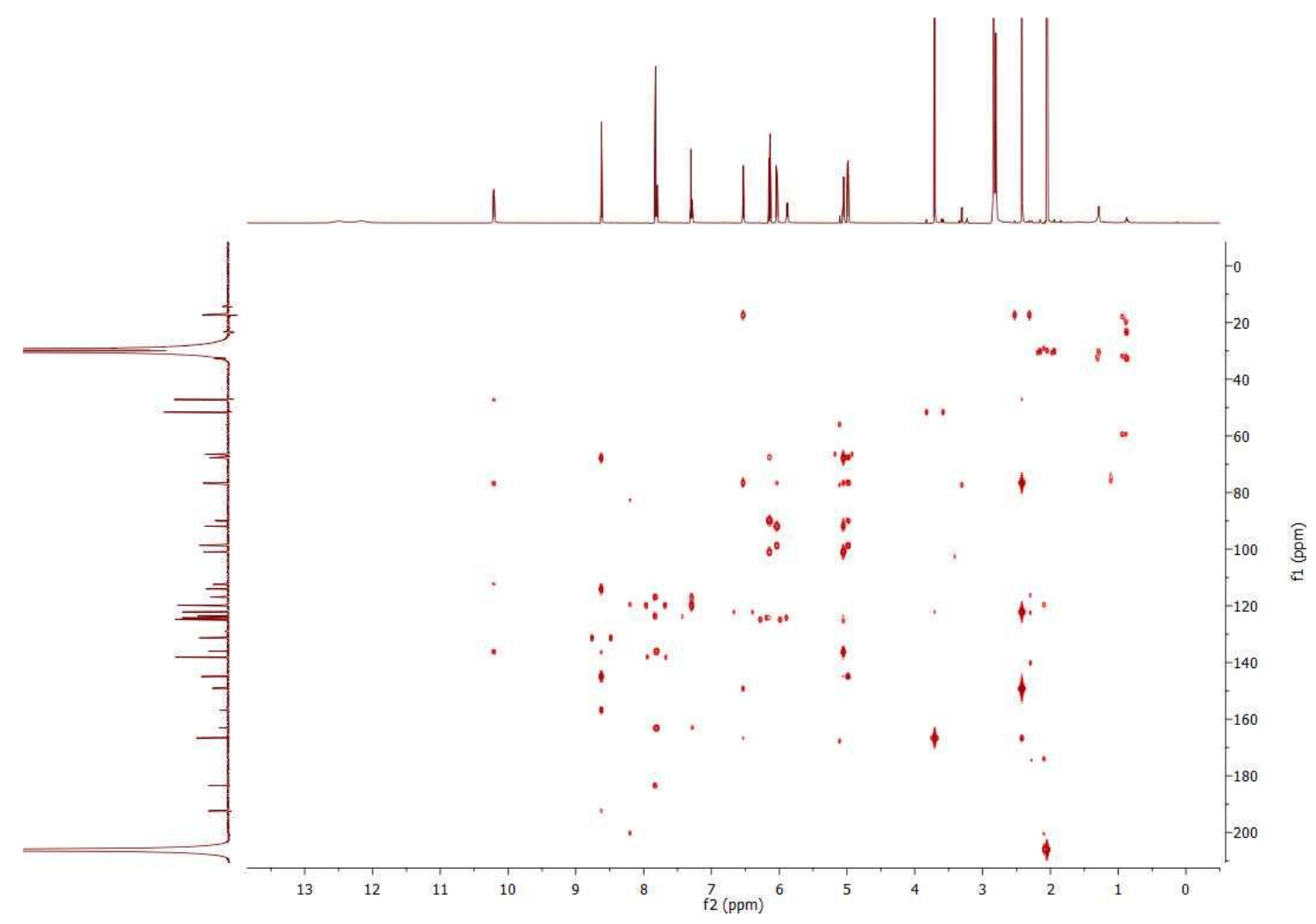

Figure S5G NOESY spectrum of $\mathbf{1 4}$ (acetone- $d_{6}$ )

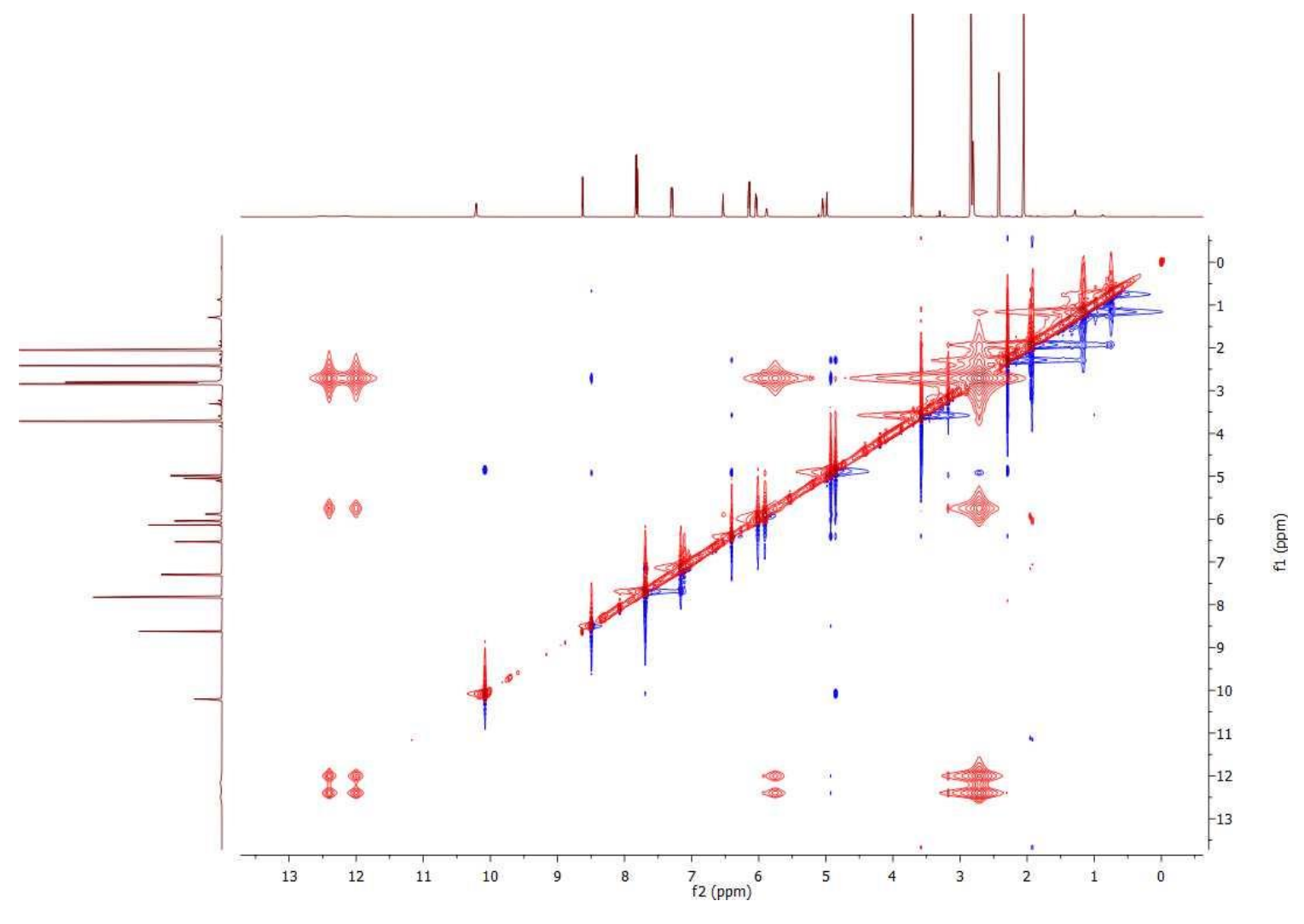


Figure S6A HR-ESI-MS spectrum of 15

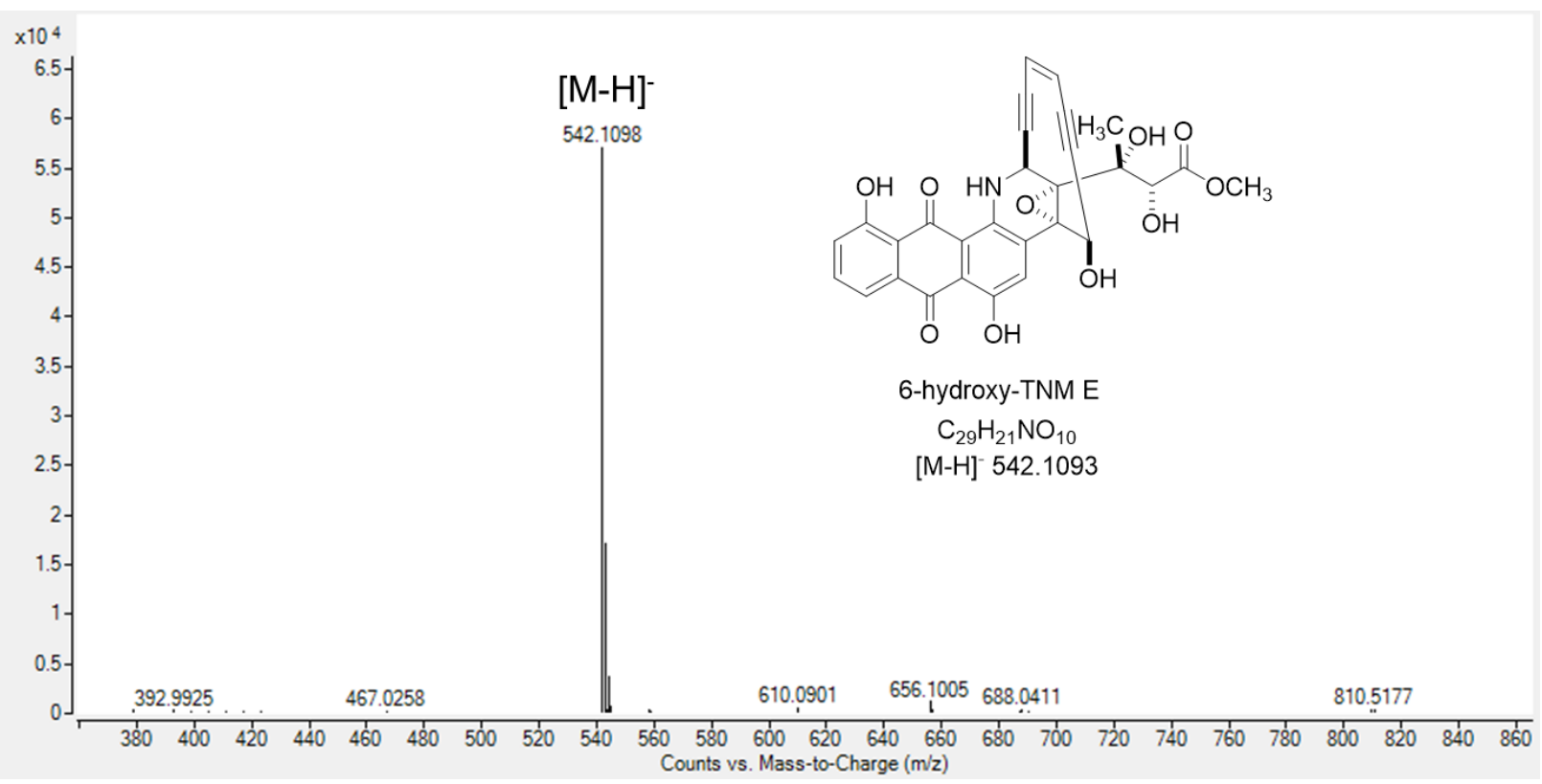


Figure S6B $\quad{ }^{1} \mathrm{H}$ NMR spectrum of $15\left(600 \mathrm{MHz}\right.$, acetone- $\left.d_{6}\right)$

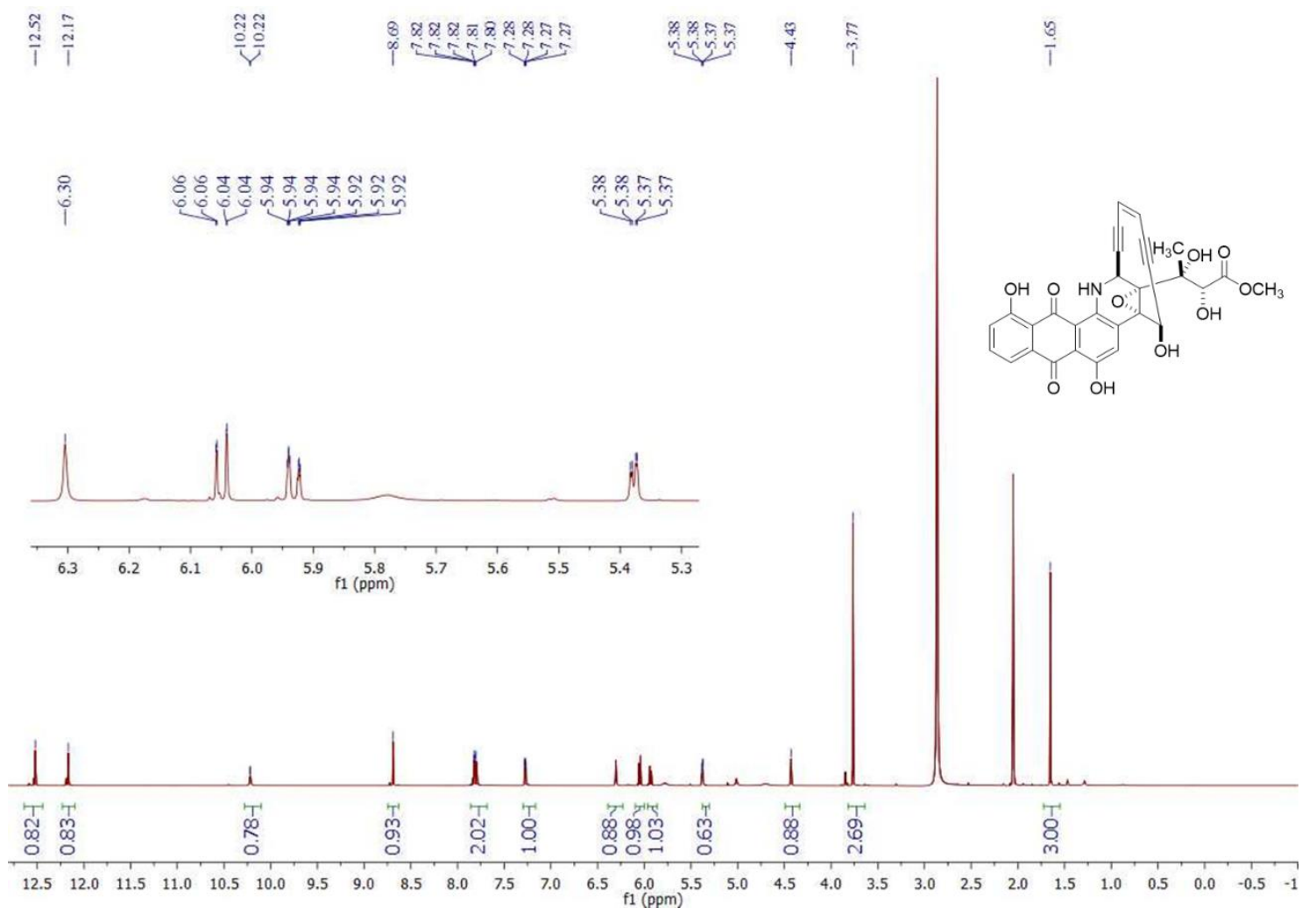

Figure S6C $\quad{ }^{13} \mathrm{C}$ NMR spectrum of $15\left(150 \mathrm{MHz}\right.$, acetone- $\left.d_{6}\right)$
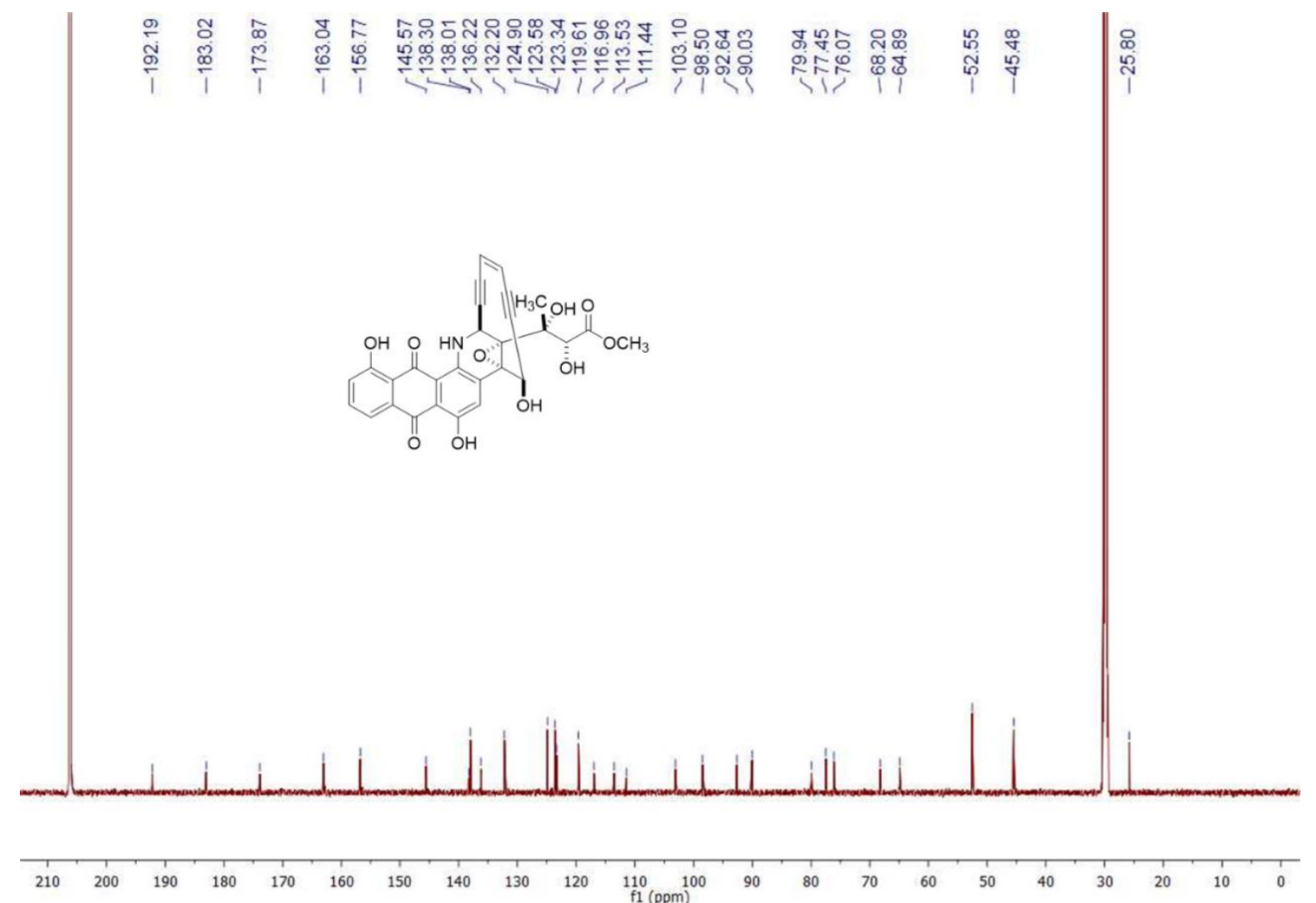
Figure S6D $\quad{ }^{1} \mathrm{H}-{ }^{1} \mathrm{H}$ COSY spectrum of 15 (acetone- $d_{6}$ )

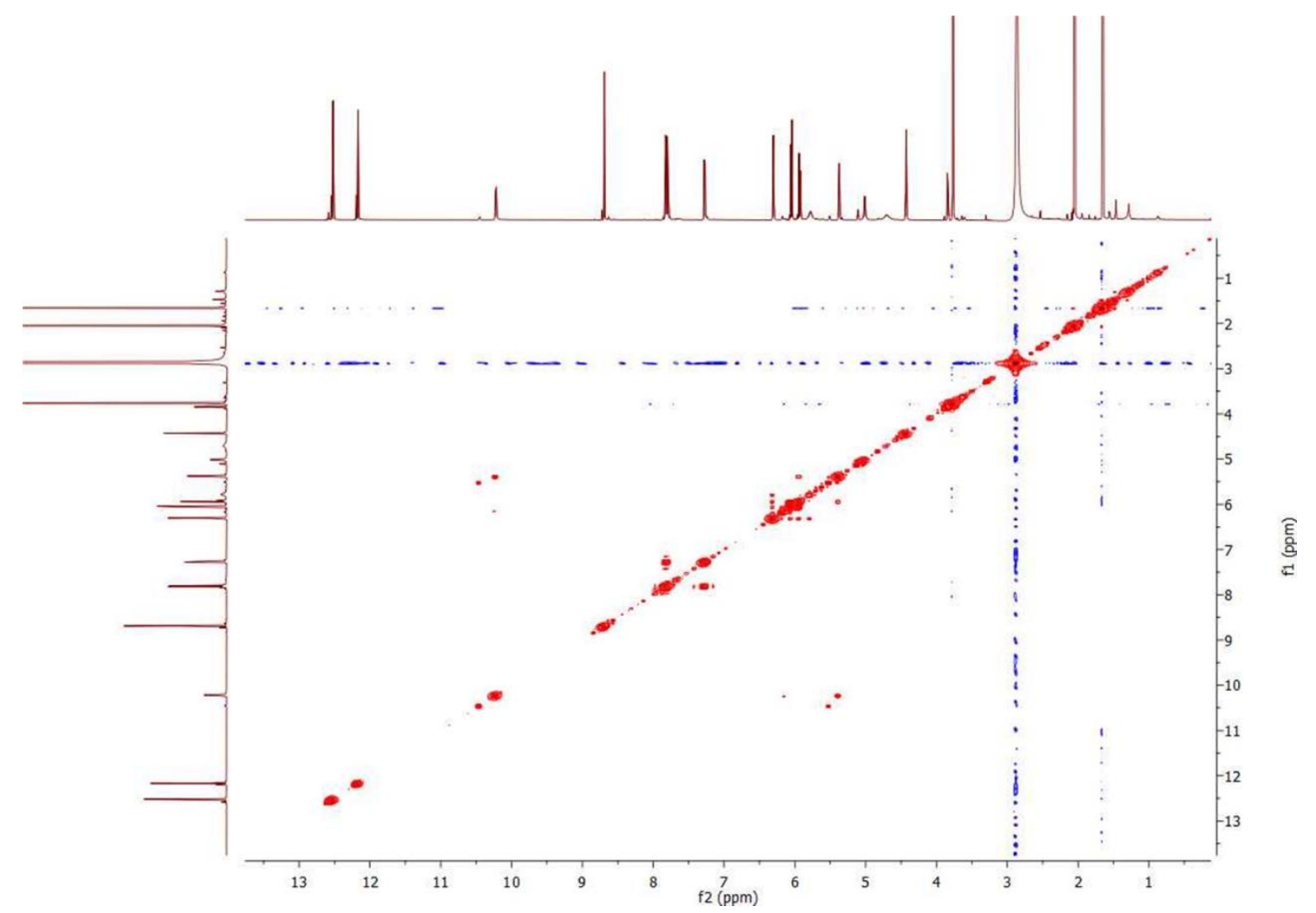

Figure S6E HSQC spectrum of 15 (acetone- $d_{6}$ )

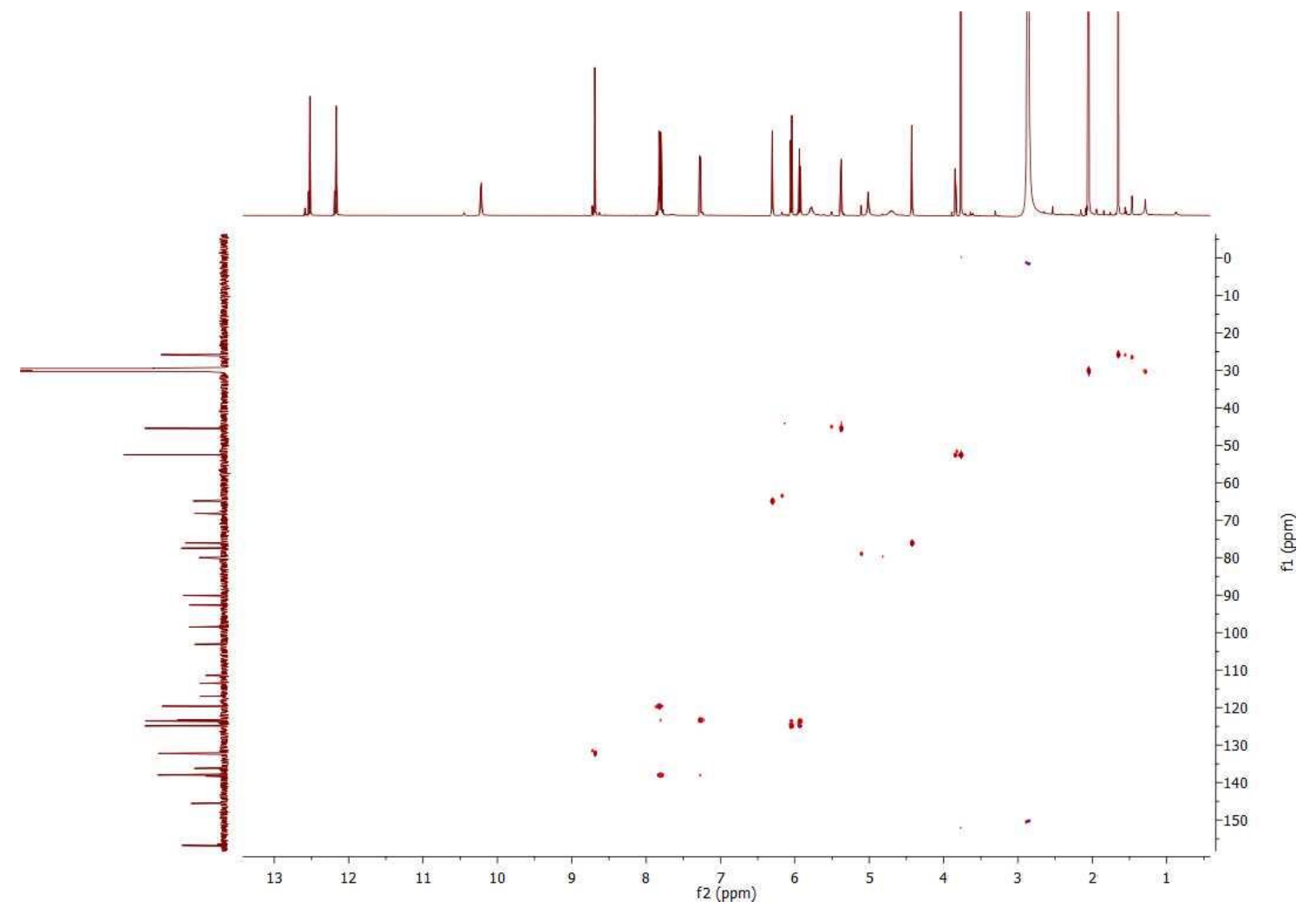


Figure S6F HMBC spectrum of $\mathbf{1 5}$ (acetone- $d_{6}$ )

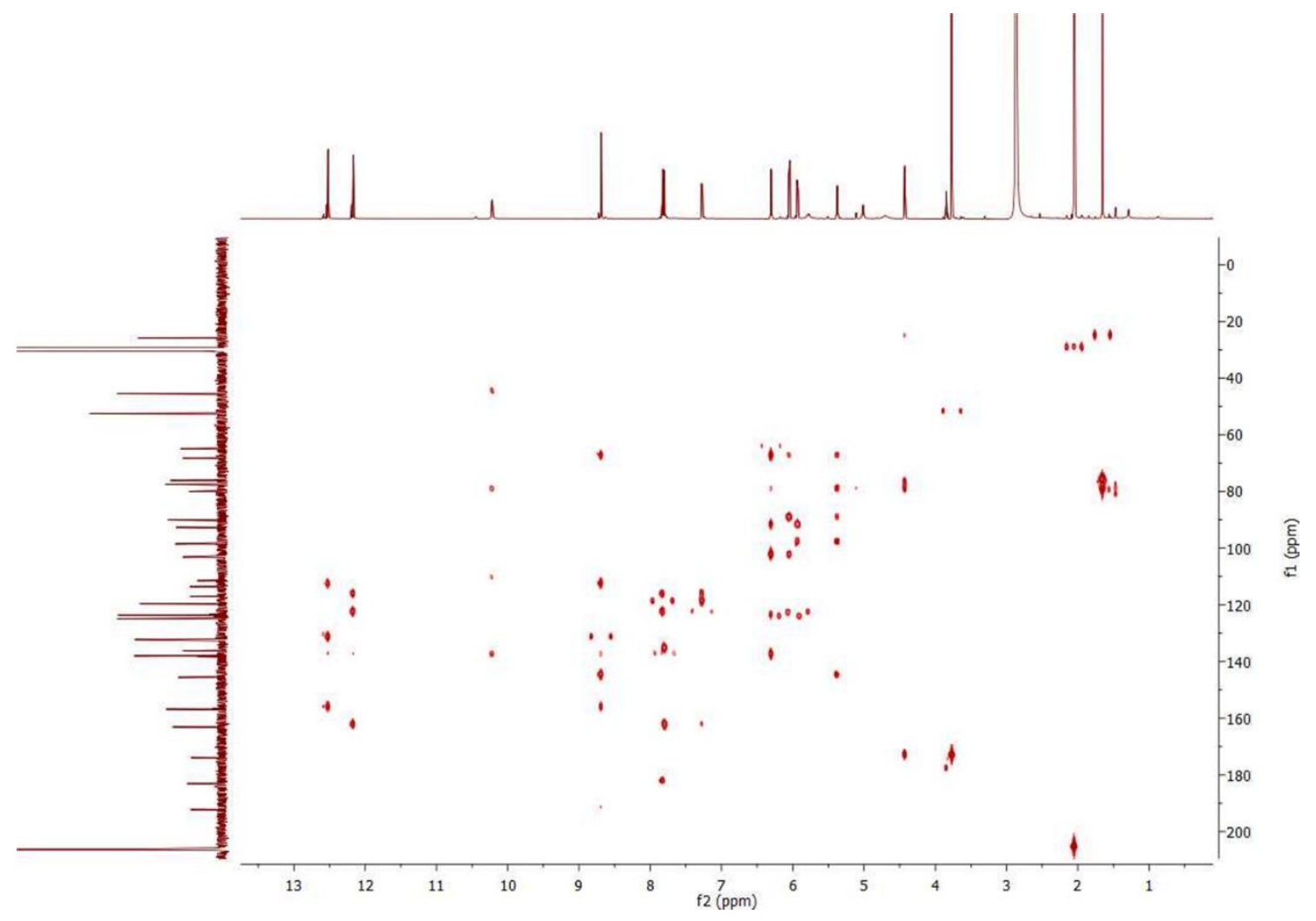

Figure S6G NOESY spectrum of $\mathbf{1 5}$ (acetone- $d_{6}$ )

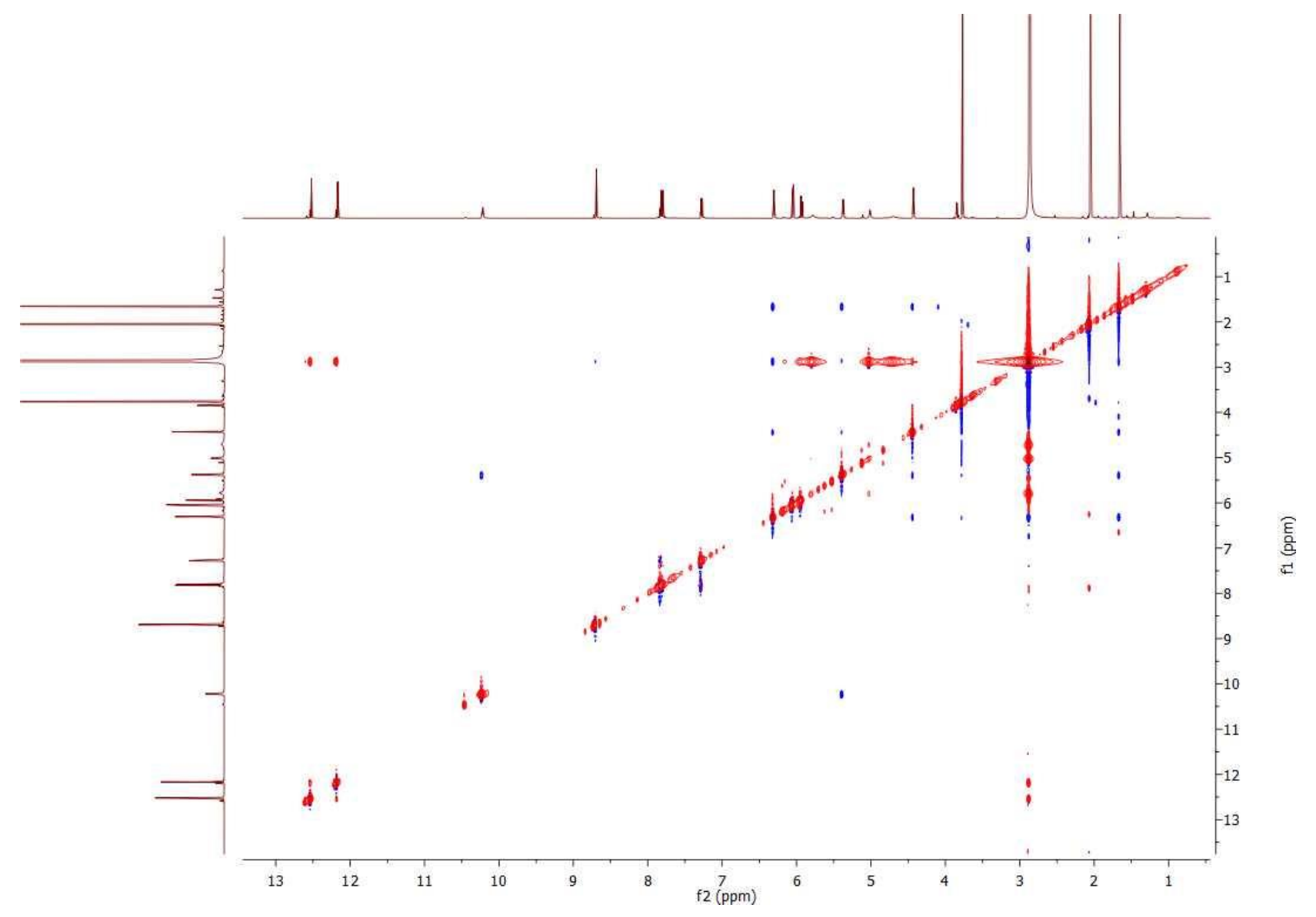


Figure S7A HR-ESI-MS spectrum of 16

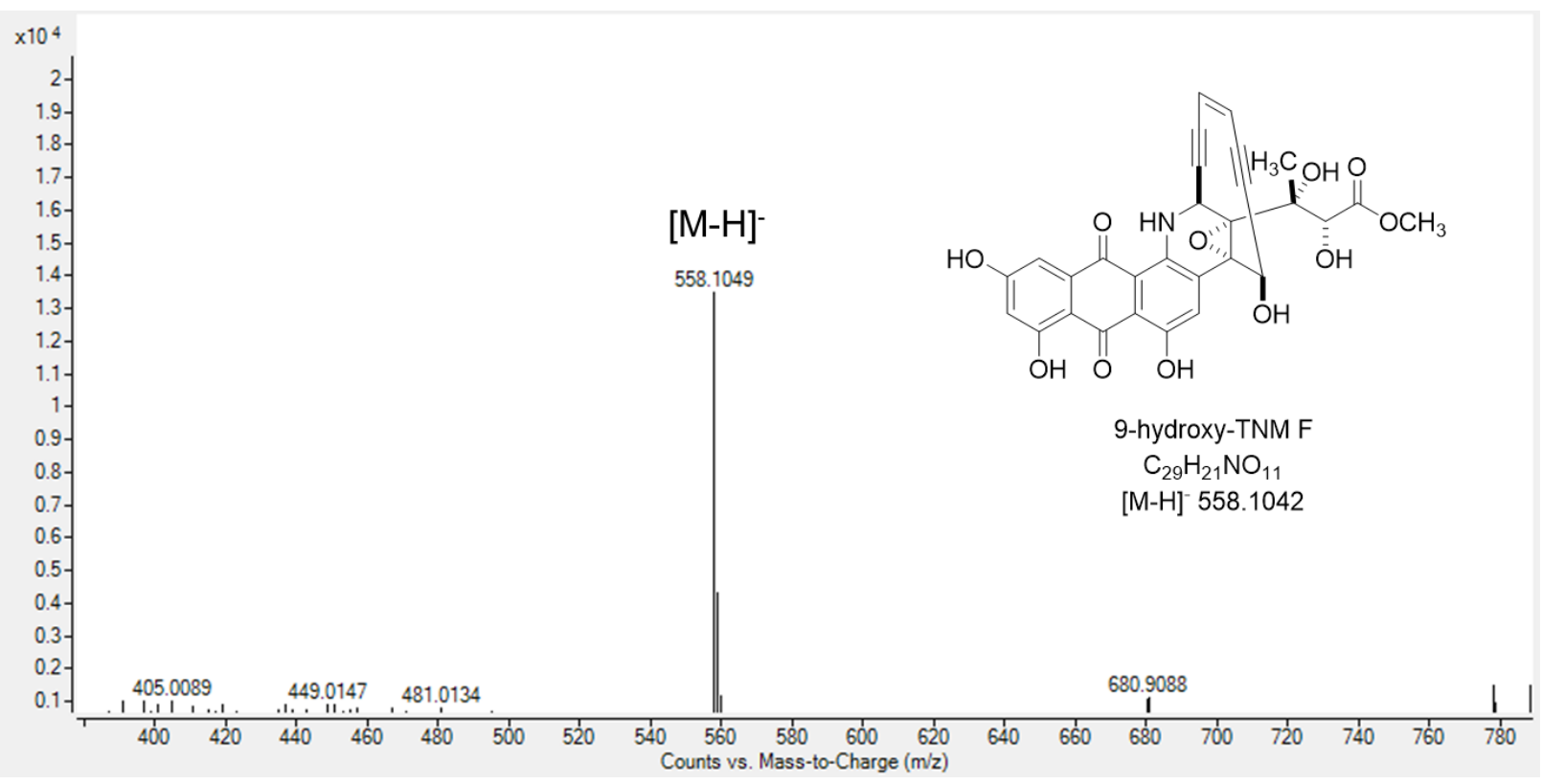


Figure S7B ${ }^{1} \mathrm{H}-\mathrm{NMR}$ spectrum of $16\left(600 \mathrm{MHz}\right.$, acetone- $\left.d_{6}\right)$

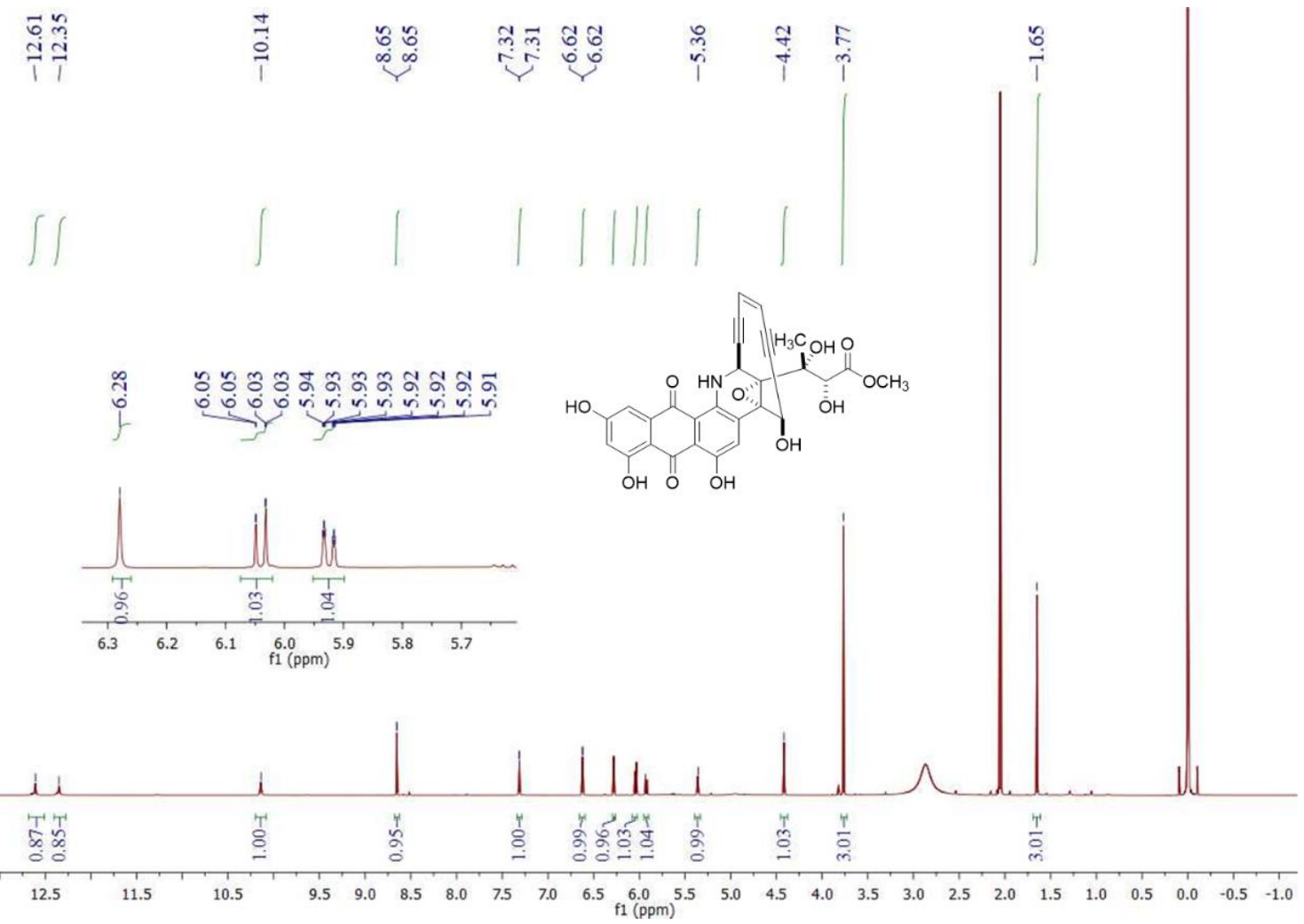

Figure S7C ${ }^{13} \mathrm{C}$ NMR spectrum of $16\left(150 \mathrm{MHz}\right.$, acetone- $\left.d_{6}\right)$
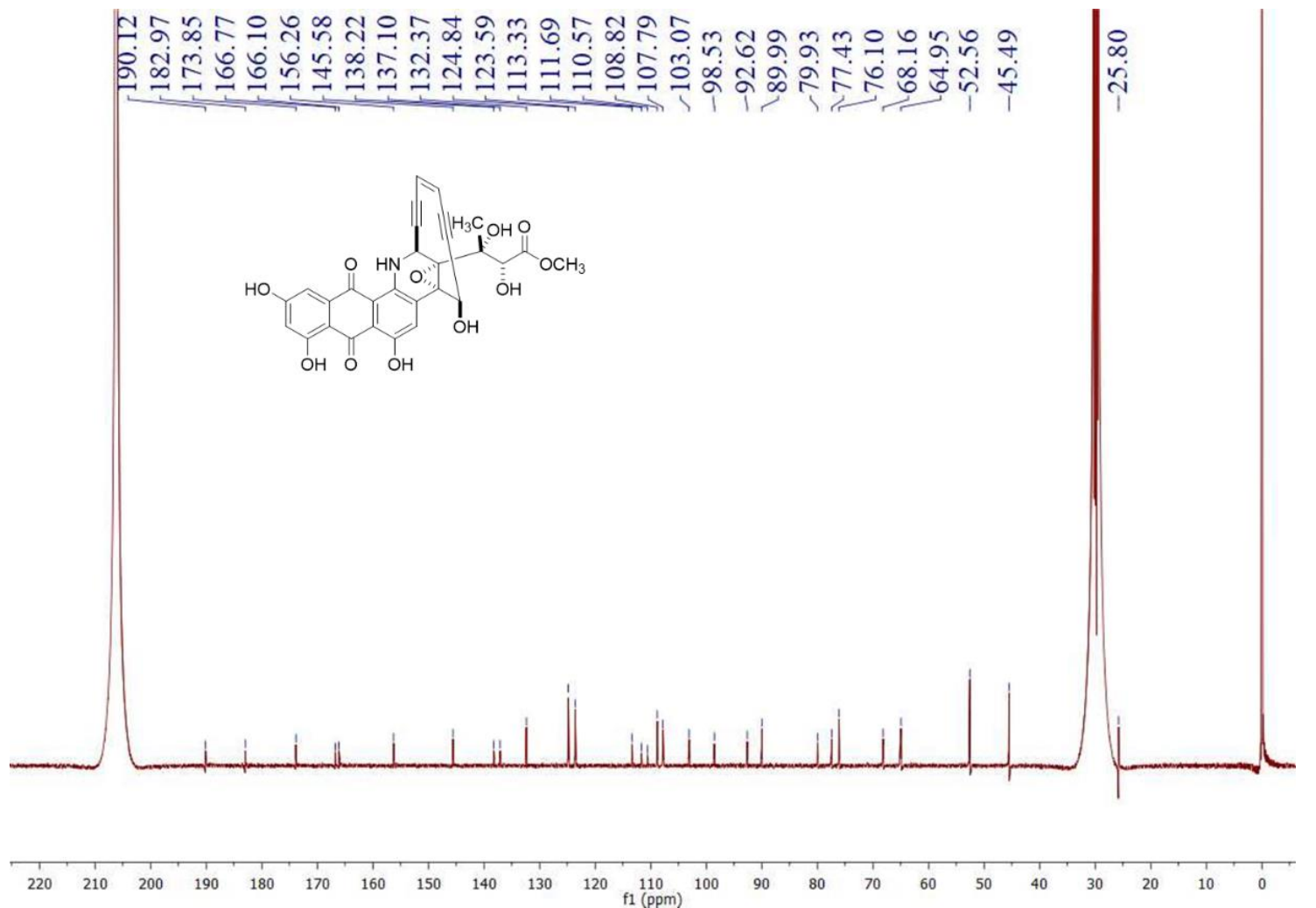
Figure S7D $\quad{ }^{1} \mathrm{H}-{ }^{1} \mathrm{H}$ COSY spectrum of 16 (acetone- $d_{6}$ )

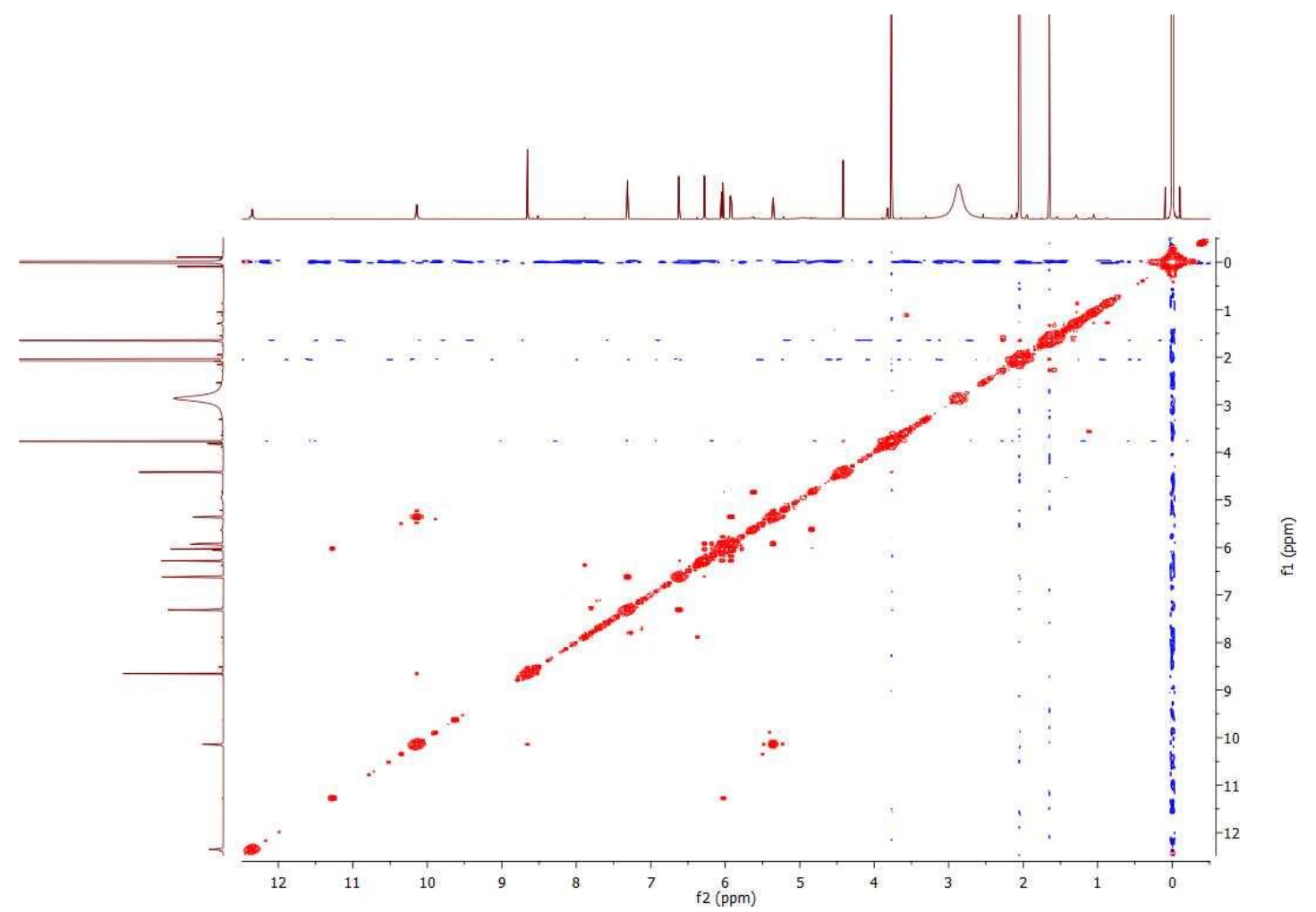

Figure S7E HSQC spectrum of 16 (acetone- $d_{6}$ )

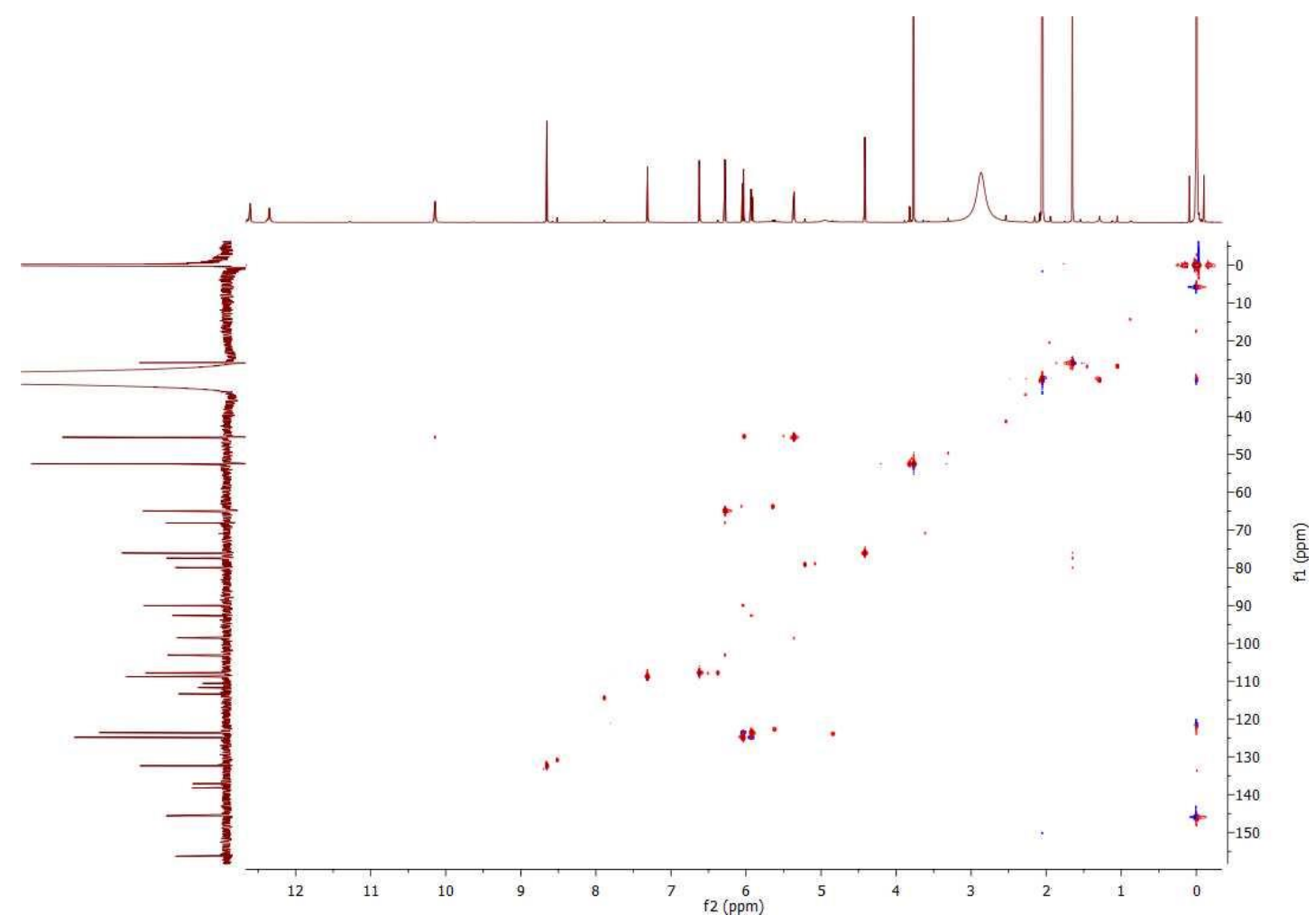


Figure S7F HMBC spectrum of $\mathbf{1 6}$ (acetone- $d_{6}$ )

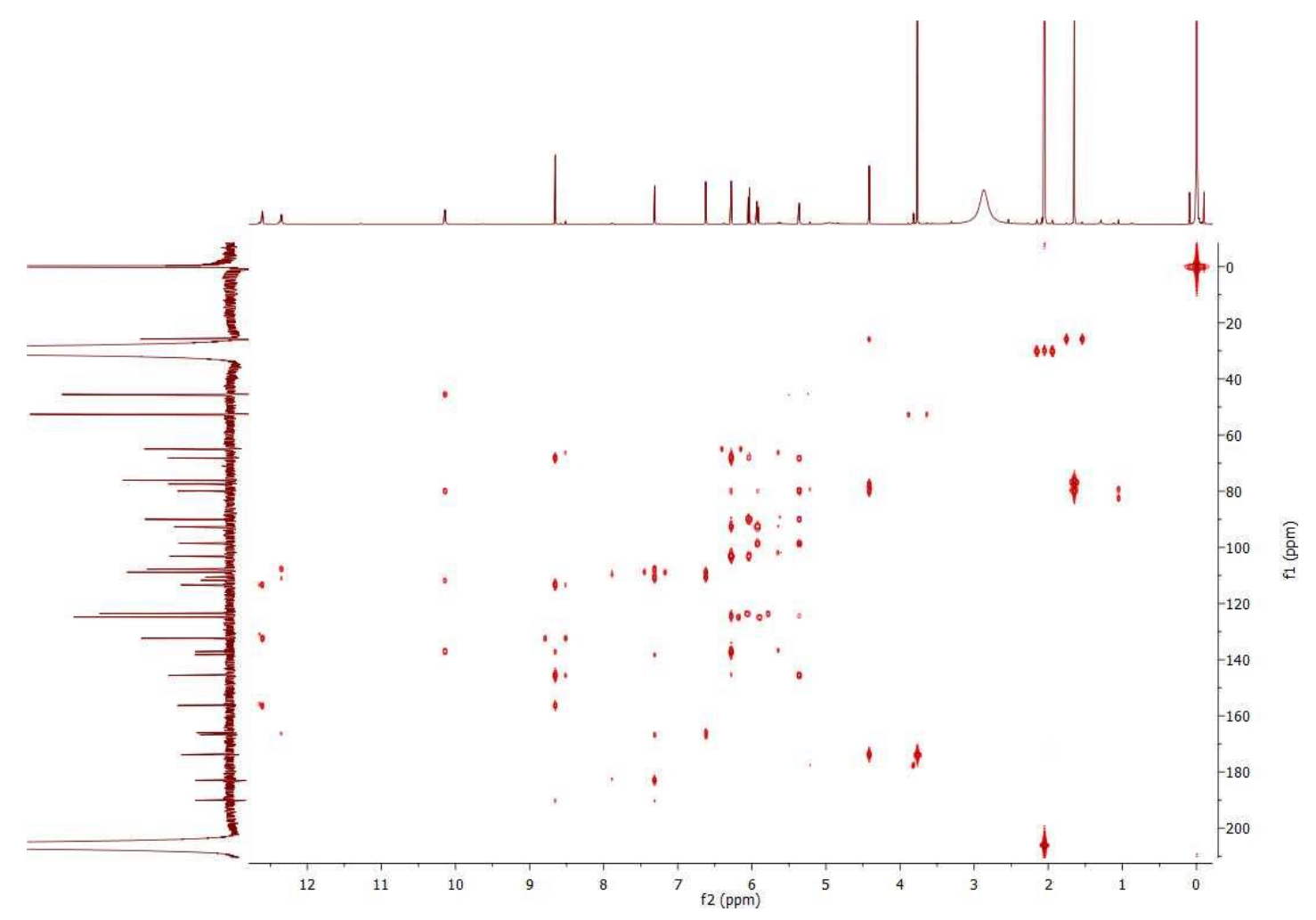

Figure S7G NOESY spectrum of 16 (acetone- $d_{6}$ )

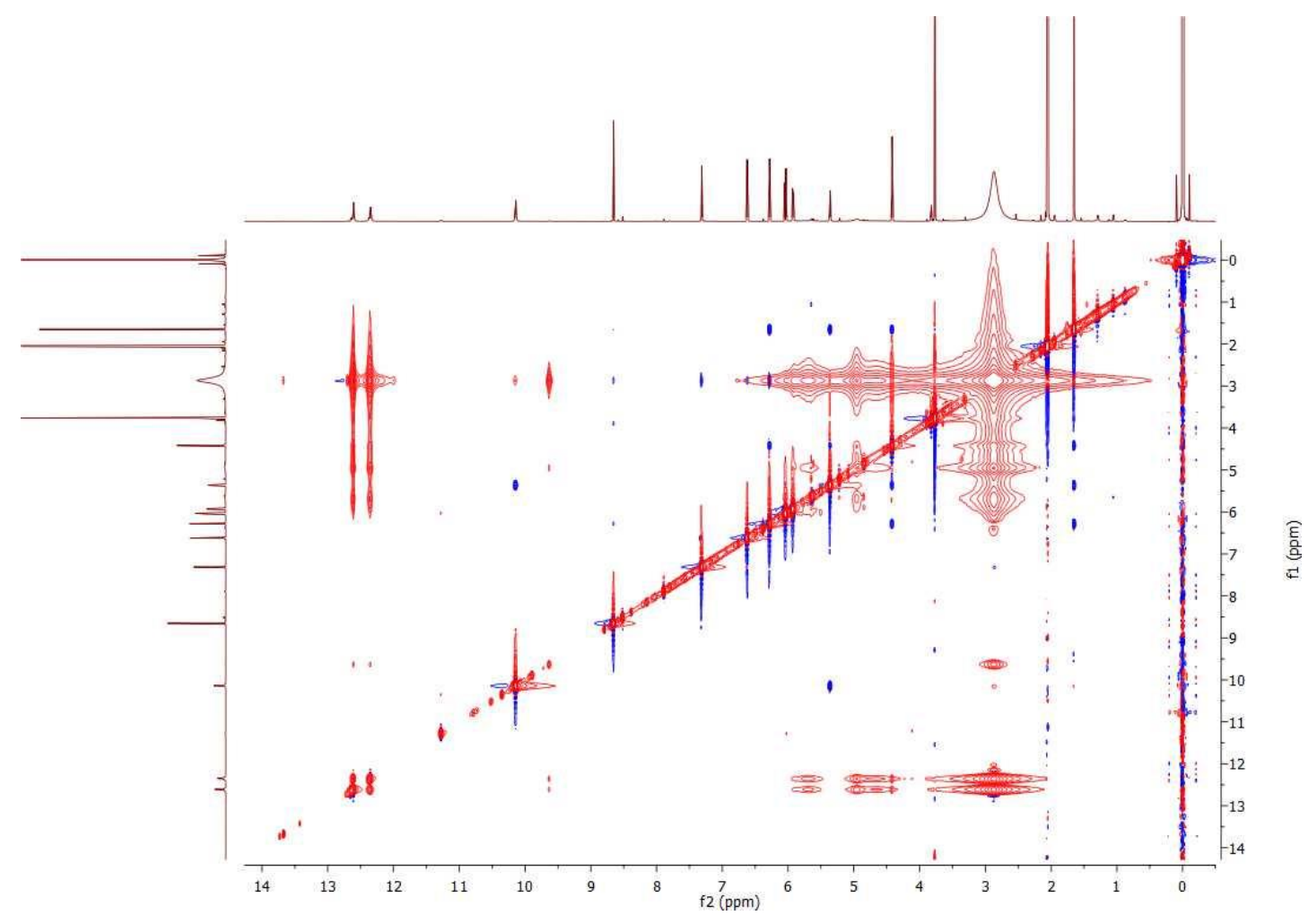


Figure S8A HR-ESI-MS spectrum of 17

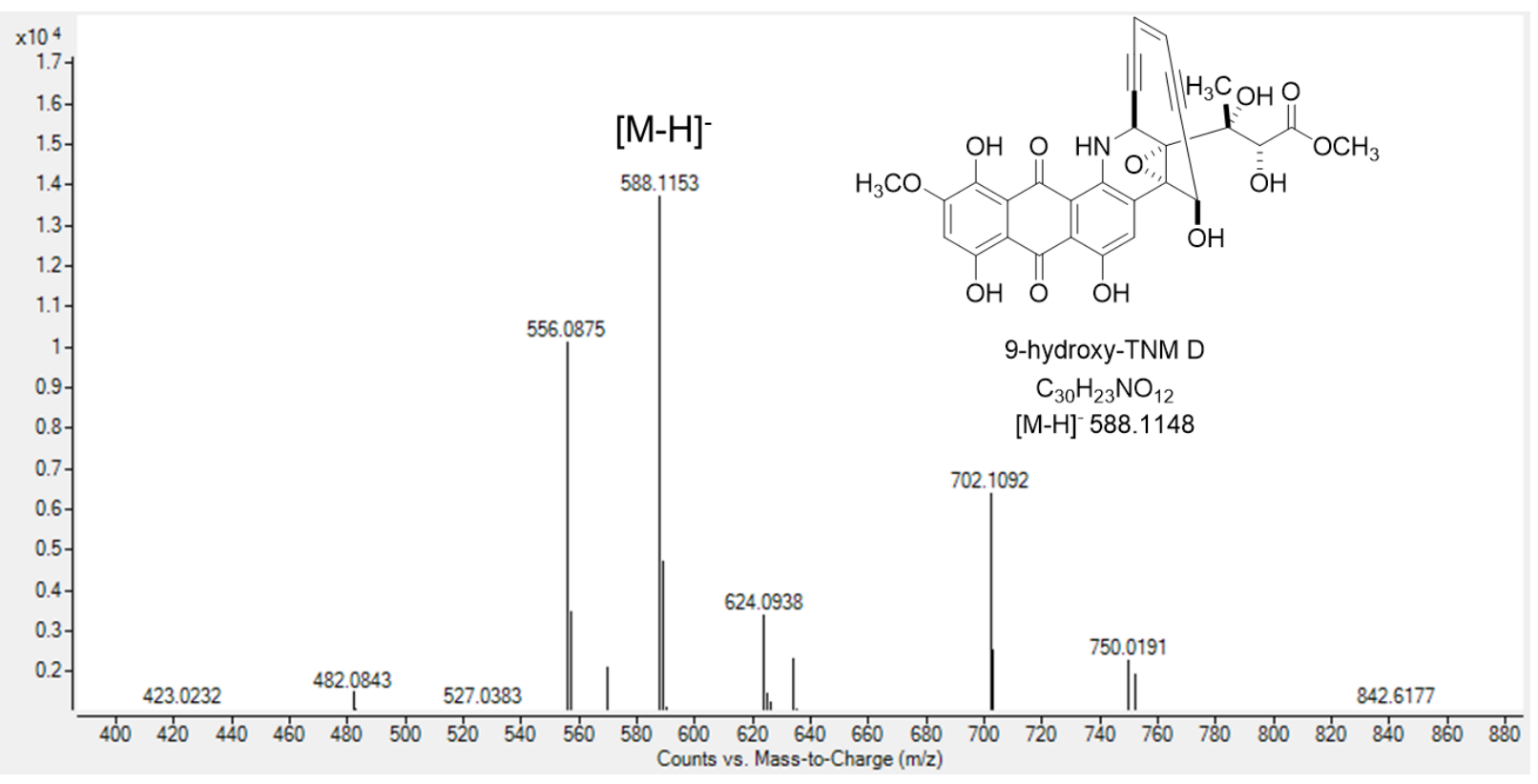


Figure S8B $\quad{ }^{1} \mathrm{H}$ NMR spectrum of $17\left(600 \mathrm{MHz}\right.$, acetone- $\left.d_{6}\right)$
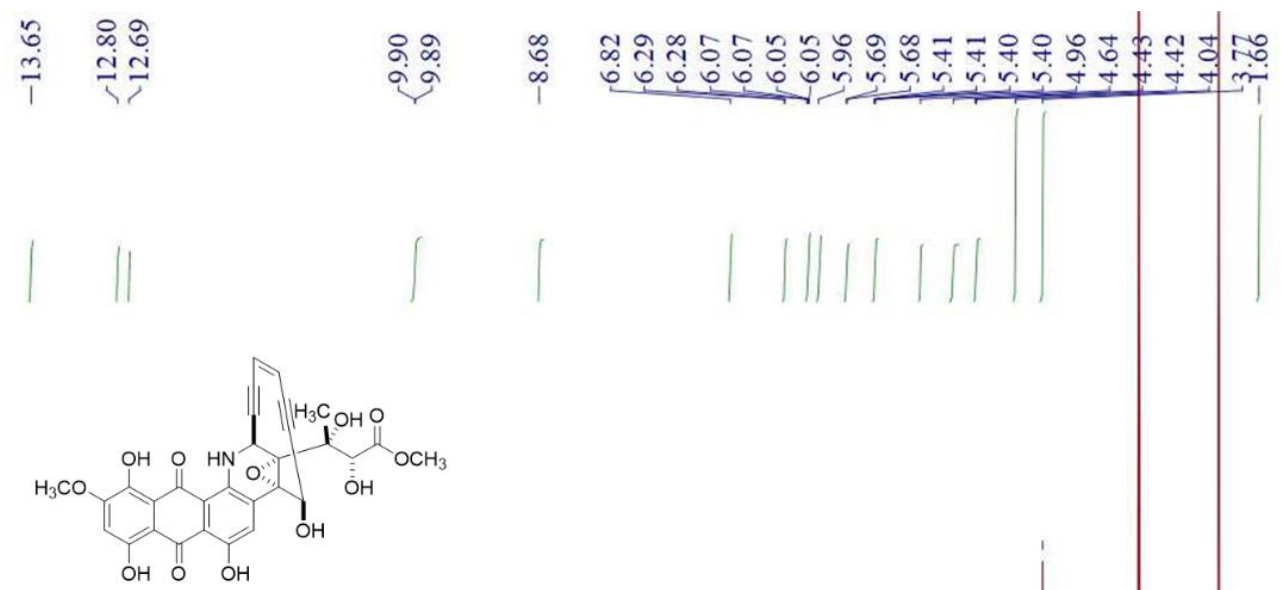

क क
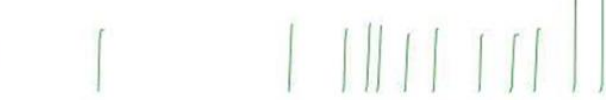
Figure S8D HSQC spectrum of $\mathbf{1 7}$ (acetone- $d_{6}$ )

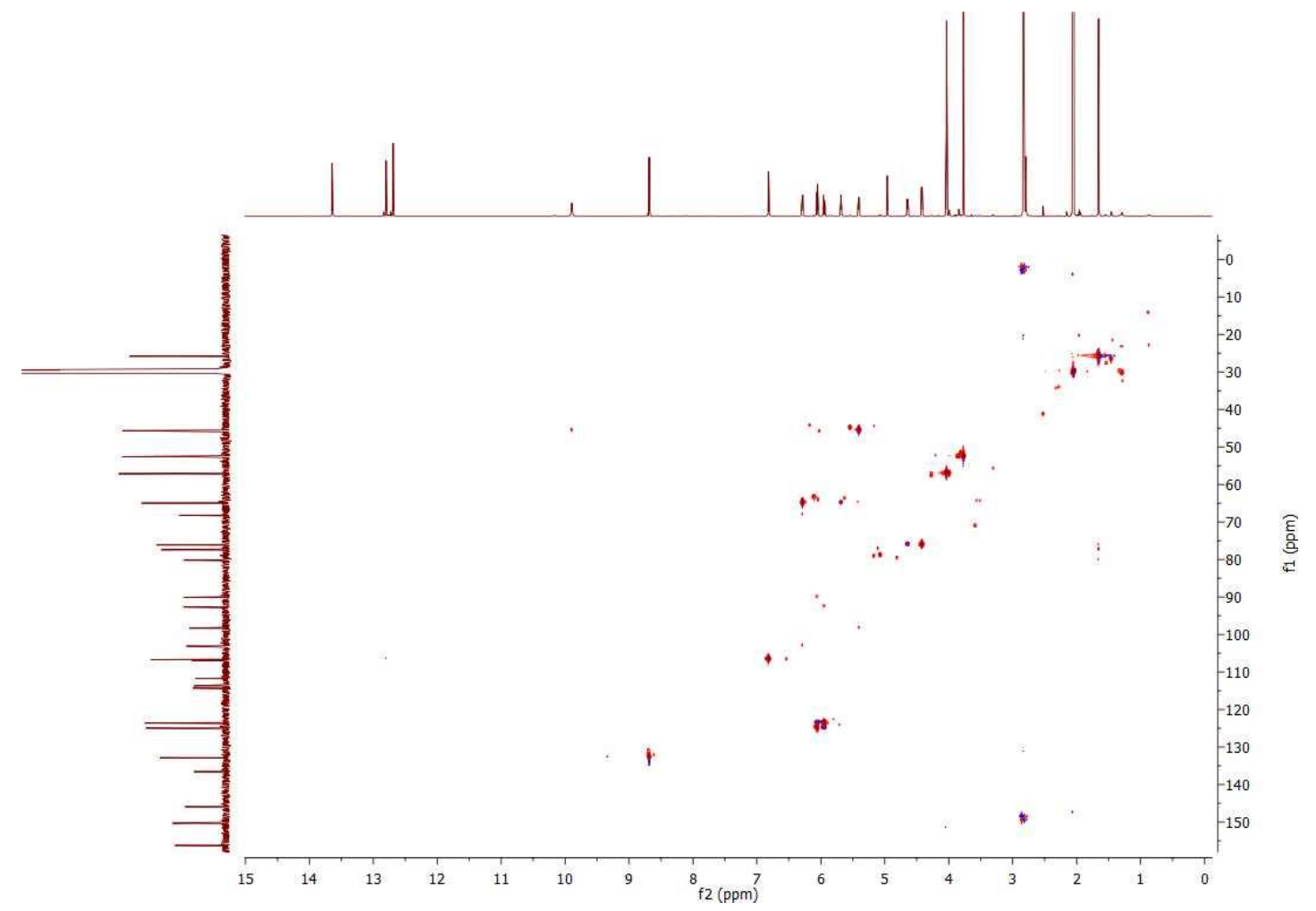

Figure S8E HMBC spectrum of $\mathbf{1 7}$ (acetone- $d_{6}$ )

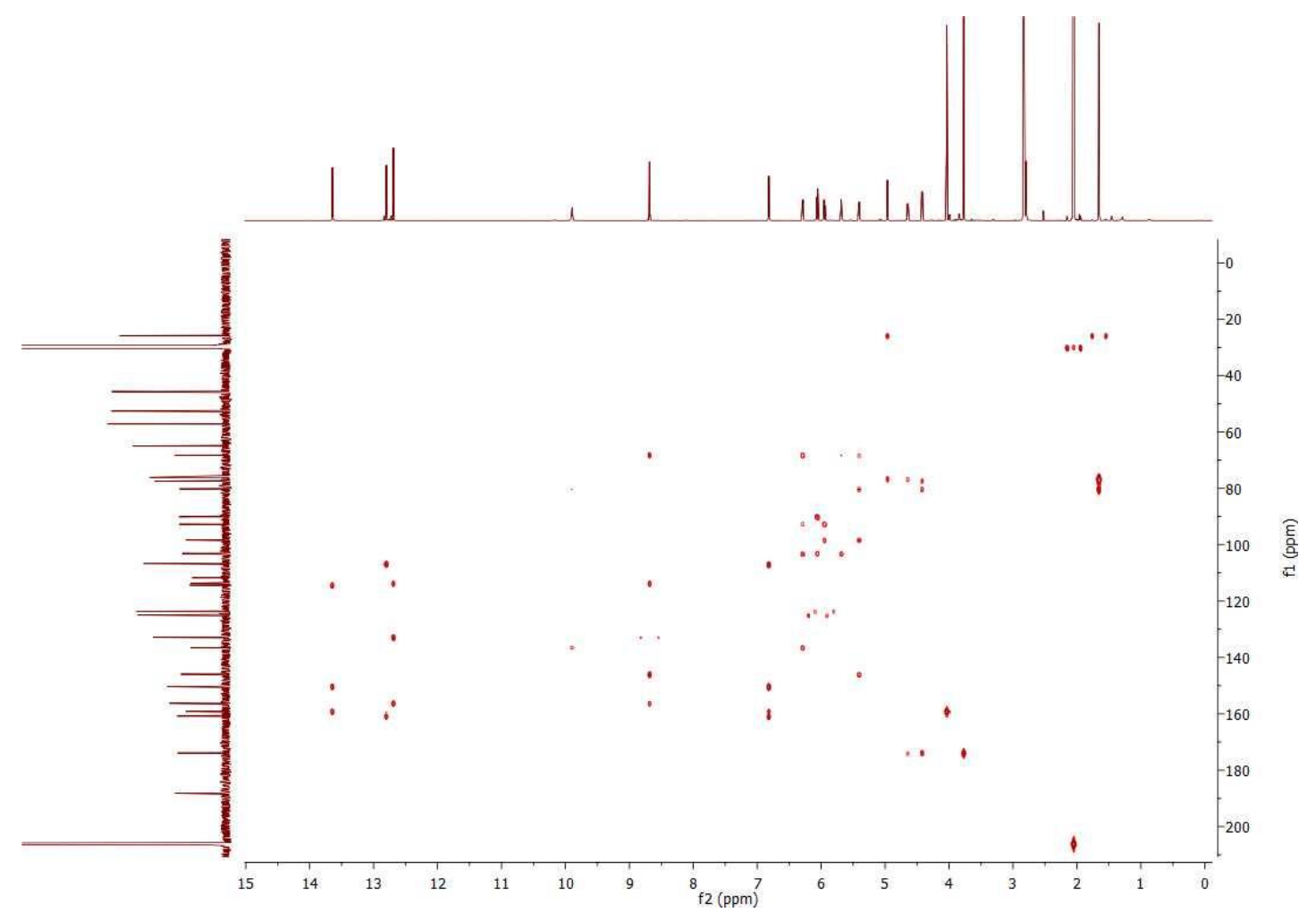


Figure S8F NOESY spectrum of $\mathbf{1 7}$ (acetone- $d_{6}$ )

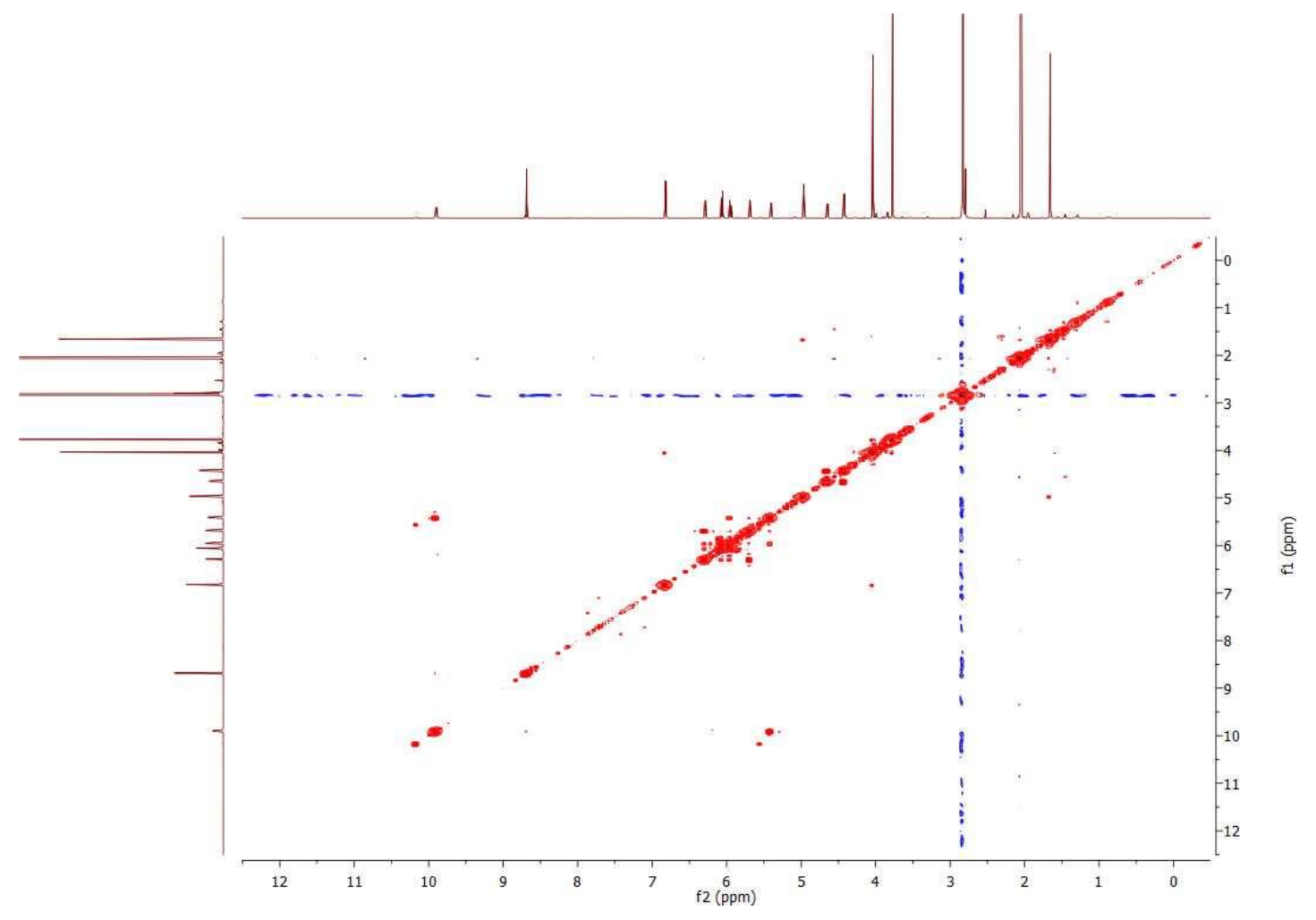


Figure S9. Key 2D NMR correlations of 14-17

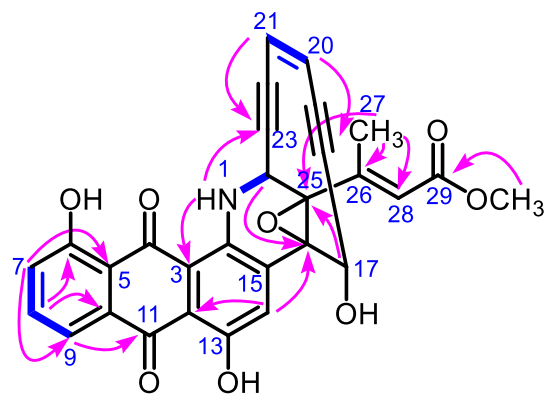

6-hydroxy-TNM B (14)

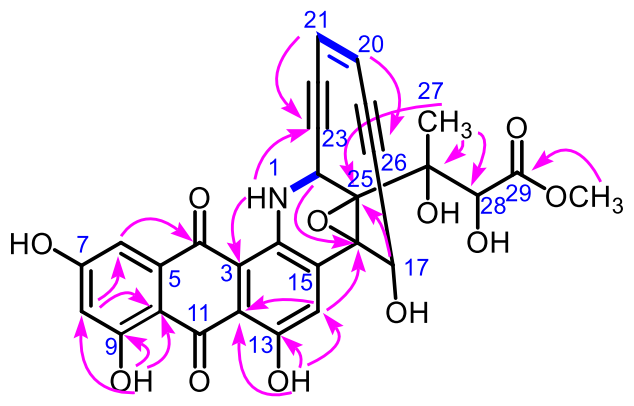

9-hydroxy-TNM F (16)

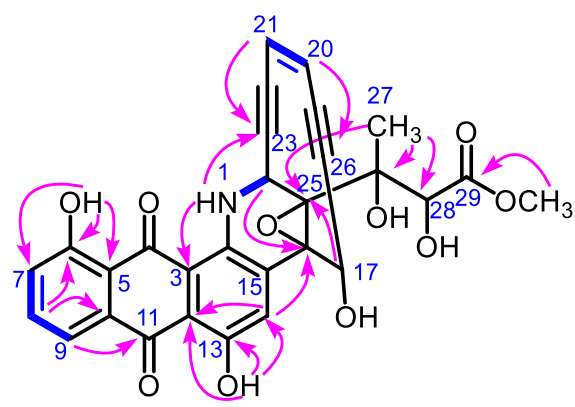

6-hydroxy-TNM E (15)

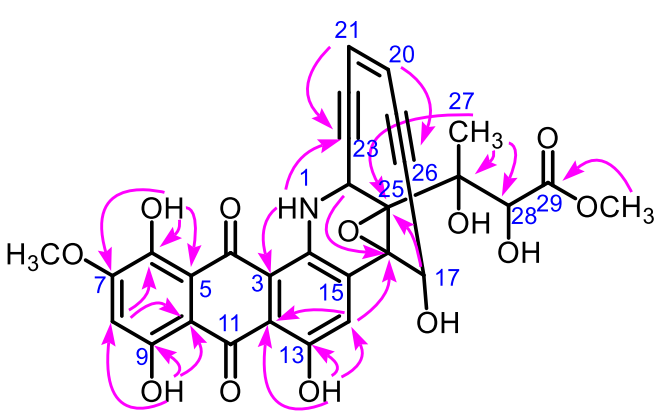

9-hydroxy-TNM D (17)

- ${ }^{1} \mathrm{H}-{ }^{1} \mathrm{H} \cos Y$

HMBC 
Figure S10. Cytotoxicity assay of 14-17 in comparison with TNM A (3) and TNM D (11)
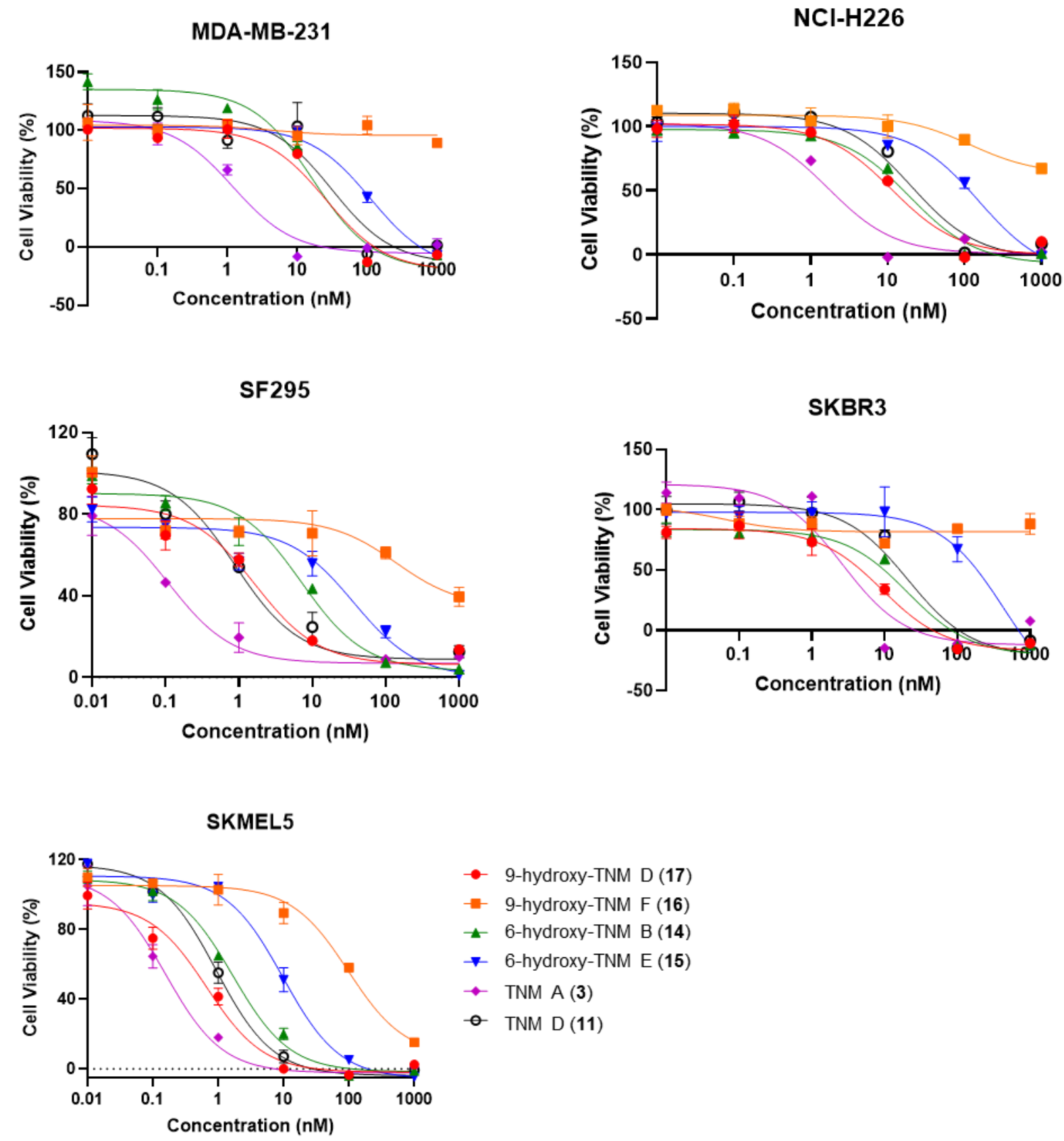

- 9-hydroxy-TNM D (17)

-1-9-hydroxy-TNM F (16)

- 6-hydroxy-TNM B(14)

$\rightarrow$ 6-hydroxy-TNM E (15)

$\rightarrow$ TNM A (3)

- TNM D(11) 
Figure S11. Plasmid relaxation assays of 14-17 in comparison with TNM A (3) and TNM D (11). (A) Schematic showing the basis of the assay involving detecting supercoiled and relaxed forms of plasmid DNA. Forms I, II, and III corresponds to supercoiled, nicked, and linearized forms of pUC19 plasmid. (B) Gel electrophoretogram showing dose-dependent relaxation of supercoiled plasmid DNA upon treatment with the TNMs. (C) Amount of supercoiled plasmid (Form I) plotted with respect to concentration of each compound 3, 11, 14-17.

A

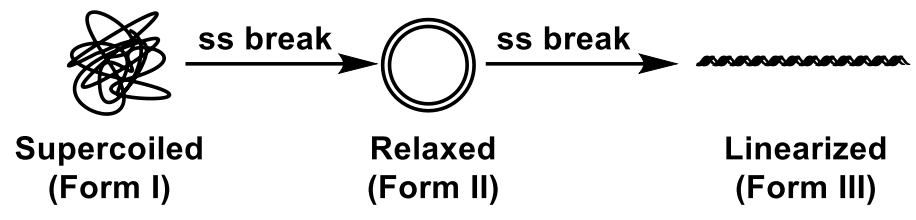

B

3

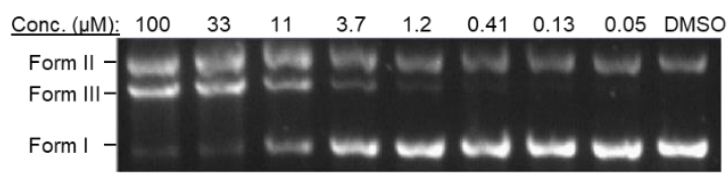

14

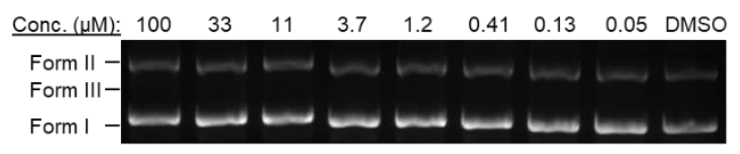

16

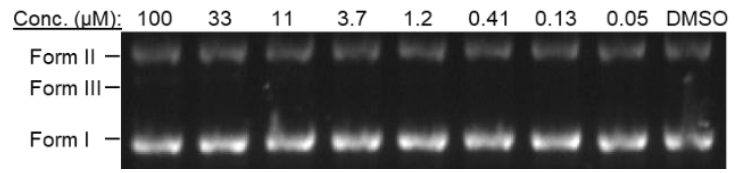

(Form III)

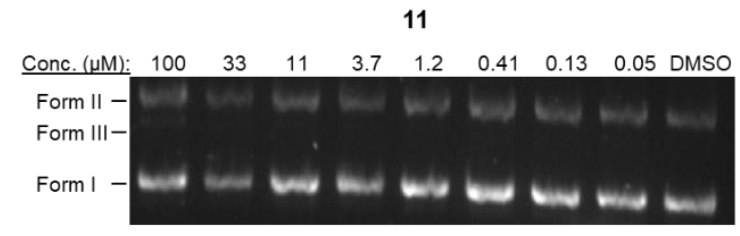

15

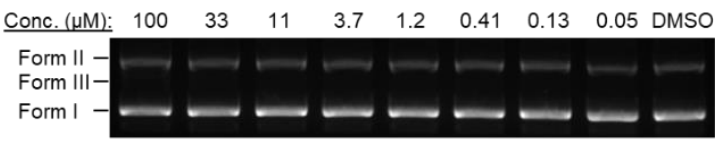

17

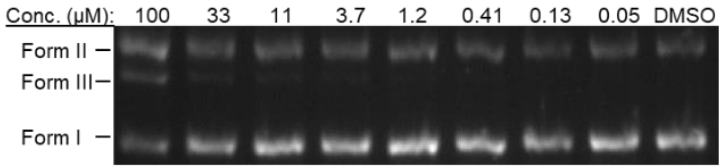

\section{C}

Plasmid Relaxation Efficacy

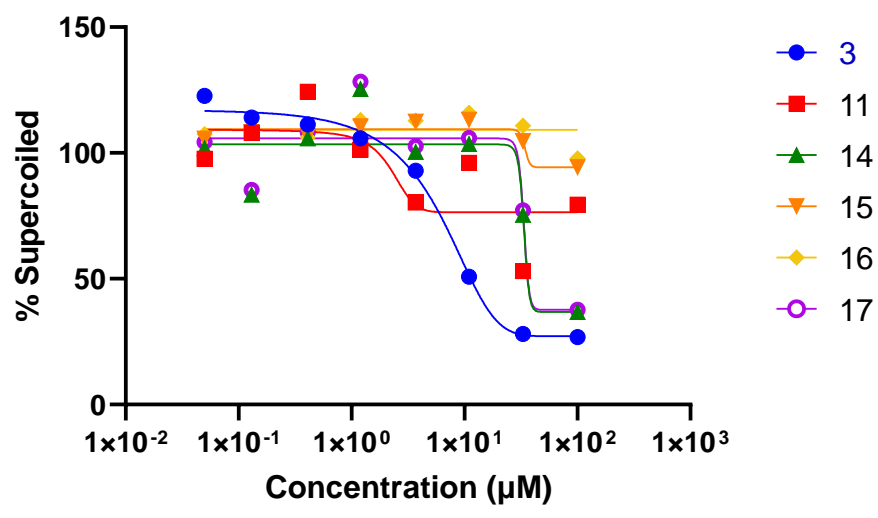




\section{SI reference}

S1. Yan, X.; Chen, J. J.; Adhikari, A.; Yang, D.; Crnovcic, I.; Wang, N.; Chang, C.-Y.; Rader, C.; Shen, B. Org. Lett. 2017, 19, 6192-6195.

S2. Lohman, J. R., Bingman, C. A., Phillips Jr, G. N., \& Shen, B. Biochemistry 2013, 52, 902-911.

S3. Aslanidis, C.; De Jong, P. J. Nucleic Acids Res. 1990, 18, 6069-6074.

S4. Guengerich, F. P.; Martin, M. V.; Sohl, C. D.; Cheng, Q. Nat. Protoc. 2009, 4, 1245-1251.

S5. Hindra; Yang, D.; Luo, J.; Huang, T.; Yan, X.; Adhikari, A.; Teijaro, C. N.; Ge, H.; Shen, B. J. Ind. Microbiol. Biotechnol. 2021, 48, kuab025.

S6. Gregory, M. A.; Till, R.; Smith, M. C. J. Bacteriol. 2003, 185, 5320-5323.

S7. Yan, X.; Ge, H.; Huang, T.; Hindra; Yang, D.; Teng, Q.; Crnovcic, I.; Li, X.; Rudolf, J. D.; Lohman, J. R.; Gansemans, Y.; Zhu, X.; Huang, Y.; Zhao, L.-X.; Jiang, Y.; Nieuwerburgh, F. V.; Rader, C.; Duan, Y.; Shen, B. mBio 2016, 7, e02104-16.

S8. Yan, X.; Chen, J. J.; Adhikari, A.; Teijaro, C. N.; Ge, H.; Crnovcic, I.; Chang, C. Y.; Annaval, T.; Yang, D.; Rader, C.; Shen, B. Org. Lett. 2018, 20, 5918-5921.

S9. Zhuang, Z.; Jiang, C.; Zhang, F.; Huang, R.; Yi, L.; Huang, Y.; Yan, X.; Duan, Y.; Zhu, X. Biotechnol. Bioeng. 2019, 116, 1304-1314.

S10. Liu, L.; Pan, J.; Wang, Z.; Yan, X.; Yang, D.; Zhu, X.; Shen, B.; Duan, Y.; Huang, Y. J. Ind. Microbiol. Biotechnol. 2018, 45, 141-151.

S11. Nicolaou, K. C.; Chen, J. S.; Zhang, H.; Montero, A. Angew. Chem., Int. Ed. 2008, 47, 185-189.

S12. Schneider, C. A.; Rasband, W. S.; Eliceiri, K. Nat. Methods 2012, 9, 671-675.

S13. Davies, J.; Wang, H.; Taylor, T.; Warabi, K.; Huang, X.-H.; Andersen, R. J. Org. Lett. 2005, 7, 5233-5236. 